\title{
EULAR recommendations for the use of imaging in the diagnosis and management of spondyloarthritis in clinical practice
}

\author{
P Mandl, ${ }_{1}^{1}$ V Navarro-Compán, ${ }^{2,3} \mathrm{~L}$ Terslev $_{1}{ }^{4} \mathrm{P}$ Aegerter, ${ }^{5} \mathrm{D}$ van der Heijde, ${ }^{2}$ \\ M A D'Agostino, ${ }^{6}$ X Baraliakos, ${ }^{7}$ S J Pedersen, ${ }^{8}$ A G Jurik, ${ }^{9}$ E Naredo, ${ }^{10}$ \\ C Schueller-Weidekamm, ${ }^{11}$ U Weber, ${ }^{12}$ M C Wick, ${ }^{13}$ P A C Bakker, ${ }^{2}$ E Filippucci, ${ }^{14}$ \\ P G Conaghan, ${ }^{15}$ M Rudwaleit, ${ }^{16} \mathrm{G} \mathrm{Schett},{ }^{17} \mathrm{~J} \mathrm{Sieper}^{16} \mathrm{~S}$ Tarp $^{18}{ }^{18} \mathrm{H}$ Marzo-Ortega, ${ }^{15}$ \\ M Østergaard ${ }^{4}$
}

\begin{abstract}
Handling editor Tore K Kvien
- Additional material is published online only. To view please visit the journal online (http://dx.doi.org/10.1136/ annrheumdis-2014-206971).
\end{abstract}

For numbered affiliations see end of article.

\section{Correspondence to} Dr Peter Mandl, Division of Rheumatology, Medical University of Vienna, 18-20 Währinger Gürtel, Vienna 1090, Austria; peter.mand@@meduniwien.ac.at

Received 11 November 2014 Revised 23 February 2015 Accepted 7 March 2015 Published Online First 2 April 2015
CrossMark

To cite: Mandl P, NavarroCompán V, Terslev L, et al. Ann Rheum Dis

2015;74:1327-1339.

\section{ABSTRACT}

A taskforce comprised of an expert group of 21 rheumatologists, radiologists and methodologists from 11 countries developed evidence-based recommendations on the use of imaging in the clinical management of both axial and peripheral

spondyloarthritis (SpA). Twelve key questions on the role of imaging in SpA were generated using a process of discussion and consensus. Imaging modalities included conventional radiography, ultrasound, magnetic resonance imaging, computed tomography (CT), positron emission tomography, single photon emission CT, dualemission $\mathrm{x}$-ray absorptiometry and scintigraphy. Experts applied research evidence obtained from systematic literature reviews using MEDLINE and EMBASE to develop a set of 10 recommendations. The strength of recommendations (SOR) was assessed by taskforce members using a visual analogue scale. A total of 7550 references were identified in the search process, from which 158 studies were included in the systematic review. Ten recommendations were produced using research-based evidence and expert opinion encompassing the role of imaging in making a diagnosis of axial SpA or peripheral SpA, monitoring inflammation and damage, predicting outcome, response to treatment, and detecting spinal fractures and osteoporosis. The SOR for each recommendation was generally very high (range 8.9-9.5). These are the first recommendations which encompass the entire spectrum of SpA and evaluate the full role of all commonly used imaging modalities. We aimed to produce recommendations that are practical and valuable in daily practice for rheumatologists, radiologists and general practitioners.

The group of spondyloarthritides comprises a number of closely related rheumatic diseases with common clinical features, ${ }^{1}$ including ankylosing spondylitis (AS), psoriatic arthritis (PsA), arthritis/ spondylitis related to inflammatory bowel disease and reactive arthritis (ReA). ${ }^{2-6}$

In addition to these subtypes, patients with spondyloarthritis $(\mathrm{SpA})$ can also be grouped into two categories based on their predominant clinical presentation: axial and peripheral. ${ }^{12}$ This division was reflected in the Assessment of Spondyloarthritis International Society (ASAS) classification criteria, which separated axial and peripheral SpA (axSpA and $\mathrm{pSpA}) .^{78}$ Imaging is a key component of classification criteria for SpA, primarily due to the lack of specific clinical symptoms as well as varying disease activity over time. For example, radiographic sacroiliitis is an essential part of the internationally accepted modified New York criteria for AS. ${ }^{4}$ Significant advances have been made within the field of imaging in SpA over the past decade. Several imaging modalities are now available that may aid in the diagnosis and monitoring of both axSpA and pSpA as well as in predicting structural damage and treatment response. However, conventional radiography (radiography) only visualises the late structural consequences of the inflammatory process, while the early inflammatory changes can be detected by MRI, often several years before the appearance of sacroiliitis on radiography. ${ }^{9}$ Accordingly, MRI was incorporated in the ASAS classification criteria for axSpA as well as pSpA. ${ }^{7}$

Reflecting the perceived need for developing evidence-based recommendations on the use of musculoskeletal imaging in the clinical management of SpA, a European League Against Rheumatism (EULAR) taskforce was convened to develop evidence-based recommendations on the use of musculoskeletal imaging in the clinical management of $\mathrm{SpA}$, for rheumatologists, radiologists and general practitioners.

\section{METHODS}

An expert group of 21 rheumatologists, radiologists and methodologists representing 11 countries formed the taskforce. The objectives were to formulate key clinical questions relating to the role of imaging in $\mathrm{SpA}$, to identify and critically appraise the available evidence, and to generate recommendations based on both evidence and expert opinion.

At the initial taskforce meeting, members proposed clinically relevant questions related to key aspects of the use of imaging in SpA. Twelve final research questions (Q1-12) were formulated and agreed upon by consensus, encompassing the full spectrum of the role of imaging in diagnosing axSpA or pSpA, monitoring inflammation and damage, predicting outcome and response to treatment, as well as detecting spinal fractures and 
osteoporosis (see online supplementary material S1: research questions).

Three systematic literature searches were performed using MEDLINE and EMBASE databases. The first search summarised research questions 1-10 (Q1-10) (questions on the diagnostic, monitoring and predictive role of imaging), while the research question on the detection of spinal fractures (Q11) and that on the detection of osteoporosis (Q12) were covered by independent searches. Specific medical subject headings and additional keywords were used to identify all relevant studies (see online supplementary material S2: search strategy). In addition, abstract archives of relevant international rheumatology and radiology meetings $(2011,2012)$ as well as the bibliographies of included papers were hand searched for evidence of other studies for inclusion. Titles and abstracts of all citations identified were screened, and potentially relevant articles were reviewed in full text using predetermined inclusion and exclusion criteria.

Studies published in English up to January 2013, on the use of imaging in adults ( $\geq 18$ years) with a suspected or established clinical diagnosis of SpA (including inflammatory and low back pain for the research question on the diagnostic role of imaging in axSpA), axSpA or $\mathrm{pSpA}$ (and suspicion of spinal (vertebral) fracture with regard to Q11), were included. Imaging modalities included radiography, ultrasound (US), MRI, CT, positron emission tomography, single-photon emission CT (SPECT), quantitative sacroiliac (SI) joint scintigraphy (QSS) and dual-energy X-ray absorptiometry (DXA). Study types included randomised controlled trials (RCTs), systematic reviews, controlled clinical trials, cohort, case-control and diagnostic studies.

Studies not in English language, those including patients $\leq 18$ years of age and those reporting data acquired from $<20$ patients with suspected or established disease (and/or $<20$ control patients for questions 1-2 on the diagnostic role of imaging) were excluded. Quality assessment of all included studies was done using the QUADAS-2 tool $^{10}$ and presented graphically for each research question. ${ }^{11}$

Data from the literature reviews were categorised and presented at the second taskforce meeting according to study design using a hierarchy of evidence in descending order according to quality. ${ }^{12}$ The literature review was conducted by PM, VNC and PB. Data extraction for each research question was reviewed by at least two of the above-mentioned taskforce members. Greater emphasis was given to the best available evidence, although all data were collected and reviewed. Expert evidence was cited only when available research evidence was lacking. The experts finally formulated 10 recommendations based on the 12 clinical questions through a process of discussion and consensus, followed by final wording adjustments by email exchange. The finally perceived strength of recommendation (SOR) for each proposition was scored by the experts using a $0-10$ visual analogue scale (VAS; $0=$ not recommended at all, $10=$ fully recommended) with data from the quality assessment. Scores reflected both research evidence and clinical expertise. $^{13}$

A research agenda was agreed upon by consensus following the presentation of the literature reviews.

\section{RESULTS}

The combined search for Q1-12 resulted in a total of 7550 records, of which a total of 158 articles were finally selected for inclusion in the systematic literature review. Articles that were relevant to $>1$ research question were included in the review more than once. The flow charts showing the detailed results of all three searches are shown in online supplementary figure S3.
The number of articles included for each research question is shown in online supplementary table S4. Taskforce members produced 10 recommendations based on a process of discussion. The recommendations, SOR (mean VAS and 95\% CI) and level of evidence are presented in table 1. A full reference list for articles included in each recommendation is shown in online supplementary material S5.

\section{Recommendations}

Recommendation 1: diagnosing axial SpA

A. In general, conventional radiography of the SI joints is recommended as the first imaging method to diagnose sacroiliitis as part of axial SpA. In certain cases, such as young patients and those with short symptom duration, MRI of the SI joints is an alternative first imaging method.

B. If the diagnosis of axial SpA cannot be established based on clinical features and conventional radiography, and axial SpA is still suspected, MRI of the SI joints is recommended. On MRI, both active inflammatory lesions (primarily bone marrow oedema (BME)) and structural lesions (such as bone erosion, new bone formation, sclerosis and fat infiltration) should be considered. MRI of the spine is not generally recommended to diagnose axial SpA.

C. Imaging modalities other than conventional radiography and MRI are not generally recommended in the diagnosis of axial $\mathrm{SpA}$.

*CT may provide additional information on structural damage if conventional radiography is negative and MRI cannot be performed. Scintigraphy and US are not recommended for diagnosis of sacroiliitis as part of axial $\mathrm{SpA}$.

Strength of recommendation: 9.5 (95\% CI 9.2 to 9.8).

Twenty-five studies evaluated the diagnostic utility of various imaging modalities in axSpA. ${ }^{14-38}$ Five studies reported on the diagnostic utility of radiography. ${ }^{14-18}$ They demonstrated varying sensitivity (SE) and specificity (SP) of radiography in diagnosing sacroiliitis in inflammatory back pain (IBP)/suspicion of $\mathrm{SpA}$, while one observational study reported an SE of 0.84 and an SP of 0.75 in diagnosing sacroiliitis in AS. ${ }^{14-18}$ A single study reported only fair agreement between radiography and CT in suspected sacroiliitis and many false positive results using radiography. ${ }^{18}$ Two studies reported higher SE for CT than radiography for diagnosing sacroiliitis (1 in AS, 1 in suspected SpA). ${ }^{15} 17$

Thirteen studies evaluated the diagnostic utility of MRI demonstrating varying SE and overall higher SP in patients with IBP or those with suspicion of SpA (table 2). ${ }^{19-31}$ Three studies reported SE (0.73-0.9) and SP (0.9-0.97) for SI joint BME on MRI in established AS. ${ }^{22} 23$ Wick et $a l^{26}$ reported an SE of 0.11 and an SP of 0.93 for MRI SI joint erosions for diagnosis of AS, while Weber et $a l^{25}$ reported that the combined features of SI joint erosion and/or BME increased SE to 0.98-0.96 compared with BME alone (0.91-0.83) without reducing SP and the area under the curve for diagnosis of AS. Heuft-Dorenborsch et al found that initial assessment of structural changes by radiography followed by MRI assessment of inflammation with negative radiography gives the highest returns for detecting involvement of the SI joint in patients with recent IBP. ${ }^{27}$ Finally, two studies found MRI of the SI joint superior to QSS or radiography for diagnosing sacroiliitis in IBP and SpA. ${ }^{14} 33$

With regard to MRI of the spine, three studies reported SE of and SP for corner fat lesions and corner inflammatory lesions (CILs) in patients suspected for axSpA, ${ }^{29} 3031$ while two studies reported SE and SP in established AS. ${ }^{31} 32$ Finally, Weber et al ${ }^{32}$ have demonstrated that spinal MRI adds little incremental value 
1 Axial SpA: diagnosis

A. In general, conventional radiography of the $\mathrm{SI}$ joints is recommended as the first imaging method to diagnose sacroilitis as part of axial SpA.

$9.5(9.2-9.8) \quad$ III In certain cases, such as young patients and those with short symptom duration, MRI of the $\mathrm{SI}$ joints is an alternative first imaging method.

B. If the diagnosis of axial SpA cannot be established based on clinical features and conventional radiography, and axial SpA is still suspected, MRI of the SI joints is recommended. On MRI, both active inflammatory lesions (primarily bone marrow oedema) and structural lesions (such as bone erosion, new bone formation, sclerosis and fat infiltration) should be considered. MRI of the spine is not generally recommended to diagnose axial SpA.

C. Imaging modalities, other than conventional radiography and MRI are generally not recommended in the diagnosis of axial SpA*.

2 Peripheral SpA: diagnosis

When peripheral SpA is suspected, US or MRI may be used to detect peripheral enthesitis, which may support the diagnosis of SpA. Furthermore, US or MRI might be used to detect peripheral arthritis, tenosynovitis and bursitis.

3 Axial SpA: monitoring activity

MRI of the SI joints and/or the spine may be used to assess and monitor disease activity in axial SpA, providing additional information on top of clinical and biochemical assessments. The decision on when to repeat MRI depends on the clinical circumstances. In general, STIR sequences are sufficient to detect inflammation and the use of contrast medium is not needed.

4 Axial SpA: monitoring structural changes

Conventional radiography of the $\mathrm{Sl}$ joints and/or spine may be used for long-term monitoring of structural damage, particularly new bone formation, in axial SpA. If performed, it should not be repeated more frequently than every second year. MRI may provide additional information.

5 Peripheral SpA: monitoring activity

US and MRI may be used to monitor disease activity (particularly synovitis and enthesitis) in peripheral SpA, providing additional information on top of clinical and biochemical assessments. The decision on when to repeat US/MRI depends on the clinical circumstances. US with high-frequency colour or power Doppler is sufficient to detect inflammation and the use of US contrast medium is not needed.

6 Peripheral SpA: monitoring structural changes

In peripheral SpA, if the clinical scenario requires monitoring of structural damage, then conventional radiography is recommended. MRI and/or US might provide additional information.

7 Axial SpA: predicting outcome/severity

In patients with ankylosing spondylitist (not non-radiographic axial SpA), initial conventional radiography of the lumbar and cervical spine is recommended to detect syndesmophytes, which are predictive of development of new syndesmophytes. MRI (vertebral corner inflammatory or fatty lesions) may also be used to predict development of new radiographic syndesmophytes.

8 Axial SpA: predicting treatment effect

Extensive MRI inflammatory activity (bone marrow oedema), particularly in the spine in patients with ankylosing spondylitis, might be used as a predictor of good clinical response to anti-TNF-alpha treatment in axial SpA. Thus, MRI might aid in the decision of initiating anti-TNF-alpha therapy, in addition to clinical examination and CRP.

9 Spinal fracture

When spinal fracture in axial SpA is suspected, conventional radiography is the recommended initial imaging method. If conventional radiography is negative, $\mathrm{CT}$ should be performed. MRI is an additional imaging method to CT, which can also provide information on soft tissue lesions.

10 Osteoporosis

In patients with axial SpA without syndesmophytes in the lumbar spine on conventional radiography, osteoporosis should be assessed by hip DXA and AP-spine DXA. In patients with syndesmophytes in the lumbar spine on conventional radiography, osteoporosis should be assessed by hip DXA, supplemented by either spine DXA in lateral projection or possibly QCT of the spine.

${ }^{*} \mathrm{CT}$ may provide additional information on structural damage if conventional radiography is negative and MRI cannot be performed. Scintigraphy and US are not recommended for diagnosis of sacroiliitis as part of axial SpA.

tThat is, radiographic axial spondyloarthritis.

Level of evidence (LOE): la, evidence for meta-analysis of randomised controlled trials; lb, evidence from at least one randomised controlled trial; lla, evidence from at least one controlled study without randomisation; Ilb, evidence from at least one other type of quasi-experimental study; III, evidence from non-experimental descriptive studies, such as comparative studies, correlation studies and case-control studies; IV, evidence from expert committee reports or opinions or clinical experience of respected authorities, or both $\mathrm{AP}$, anterior-posterior; CRP, C-reactive protein; DXA, dual-energy X-ray absorptiometry; EULAR, European League Against Rheumatism; nr-axSpA, non-radiographic axial spondyloarthritis; QCT, quantitative CT; SI, sacroiliac; SIJ, sacroiliac joints; SOR, strength of recommendation; SpA, spondyloarthritis; STIR, short tau inversion recovery; TNF-alpha, tumour necrosis factor alpha; US, ultrasonography.

compared with MRI of the SI joint alone in terms of lesion detection and classification of patients with early SpA. Four studies reported that QSS has low SE for diagnosis of sacroiliitis in patients with IBP $^{14}{ }^{33-35}$ Klauser et al $^{36} 37$ reported that contrast-enhanced US is a sensitive and specific tool for diagnosing active sacroiliitis in patients with IBP and AS. One study reported that pulsatile monophasic colour Doppler US detects sacroiliitis in patients with AS. ${ }^{38}$ Quality assessment is reported in online supplementary figure S6.1; of note risk of patient selection bias and applicability concerns with regard to patient selection were high in $52 \%$ and $36 \%$ of the included manuscripts, respectively.

Recommendation 2: diagnosing peripheral SpA

When peripheral $\mathrm{SpA}$ is suspected, US or MRI may be used to detect peripheral enthesitis, which may support the diagnosis of
SpA. Furthermore, US or MRI might be used to detect peripheral arthritis, tenosynovitis and bursitis.

Strength of recommendation: 9.4 (95\% CI 9.0 to 9.8 )

Nine studies evaluated grey-scale and/or power Doppler US (GSUS/PDUS, respectively) for assessment of entheses in patients with established $\mathrm{pSpA}^{39-47}$ using clinical examination as gold standard. Eight studies evaluated multiple entheses, ${ }^{39-46}$ while one study evaluated only the Achilles tendon. ${ }^{47}$ One study reported that PDUS has an SE of 0.76 and an SP of 0.81 in suspected $\mathrm{SpA},{ }^{41}$ while four studies reported varying $\mathrm{SE}$ and overall higher SP in established PsA. ${ }^{39}$ 45-47 Four studies reported an SE of $0.83-0.98$ and an SP of $0.48-0.9$ for PDUS assessment in established $\mathrm{pSpA}^{40-43}$ Finally, Feydy et $a l^{44}$ reported that MRI of the heel had an SP of 0.94 but SE of 0.22 for discriminating between patients with SpA and controls. 
Table 2 Recommendation 1: summary of studies on the use of MRI in diagnosing axial spondyloarthritis

\begin{tabular}{|c|c|c|c|c|c|c|c|c|c|}
\hline Studies & No. & Study population & Gold standard & SIJ/spine & MRI lesion & SE & SP & $+\mathrm{LR}$ & $-\mathrm{LR}$ \\
\hline \multicolumn{10}{|l|}{ Longitudinal/RCT } \\
\hline Bennett et $a l^{19}$ & 50 & $\mathrm{SpA}$ & X-ray & SIJ & Grade 3 SI+HLAB27 27B27 & 0.62 & 0.92 & 7.7 & 0.41 \\
\hline Marzo-Ortega et $a l^{20}$ & 76 & IBP (NSBP, HC) & Clinical diagnosis & SIJ & $\begin{array}{l}\text { Grade } 1 \mathrm{SI} \\
\text { Grade } 2 \mathrm{SI}\end{array}$ & $\begin{array}{l}0.82 \\
0.73\end{array}$ & $\begin{array}{l}0.43 \\
1.0\end{array}$ & $\begin{array}{l}1.4 \\
\infty\end{array}$ & $\begin{array}{l}0.41 \\
0.73\end{array}$ \\
\hline Oostveen et al ${ }^{21}$ & 25 & IBP & X-ray & SIJ & Grade $\geq 2 \mathrm{SI}$ & 0.85 & 0.47 & 1.6 & 0.31 \\
\hline \multicolumn{10}{|l|}{ Cross-sectional/case-control } \\
\hline Weber et $a l^{22} 23$ & 187 & AS, IBP (NSBP, HC) & Clinical diagnosis & SIJ & $\begin{array}{l}\text { BME (AS) } \\
\text { BME (IBP) } \\
\text { BME+ERO }\end{array}$ & $\begin{array}{l}0.9 \\
0.51 \\
0.81\end{array}$ & $\begin{array}{l}0.97 \\
0.97 \\
0.97\end{array}$ & $\begin{array}{l}44.6 \\
26 \\
27\end{array}$ & $\begin{array}{l}0.92 \\
0.50 \\
0.19\end{array}$ \\
\hline Weber et $a l^{24} 25$ & 157 & AS, IBP (NSBP, HC) & Clinical diagnosis & SIJ & $\begin{array}{l}\text { BME } \\
\text { BME and/or ERO } \\
\mathrm{FI} \\
\mathrm{FI} \text { with BME or ERO }\end{array}$ & $\begin{array}{l}0.73 \\
0.82 \\
0.21 \\
0.24\end{array}$ & $\begin{array}{l}0.9 \\
0.9 \\
0.97 \\
0.97\end{array}$ & $\begin{array}{l}7.3 \\
8.2 \\
8.3 \\
9.2\end{array}$ & $\begin{array}{l}0.3 \\
0.2 \\
0.81 \\
0.78\end{array}$ \\
\hline Heuft-Dorenbosch et al ${ }^{27}$ & 68 & IBP & X-ray & SIJ & chronic changes & 0.49 & 0.97 & 16.3 & 0.52 \\
\hline Weber et a ${ }^{\beta 0}$ & 95 & $A S, I B P,(H C)$ & Clinical diagnosis & Spine & $\begin{array}{l}>2 \text { CIL (AS) } \\
>2 \text { CIL (IBP) } \\
\text { LIL }\end{array}$ & $\begin{array}{l}0.69 \\
0.32 \\
0.97\end{array}$ & $\begin{array}{l}0.94 \\
0.96 \\
0.31\end{array}$ & $\begin{array}{l}12 \\
8 \\
1.4\end{array}$ & $\begin{array}{l}0.32 \\
0.70 \\
0.09\end{array}$ \\
\hline Kim et $a l^{31}$ & 104 & AS (HC) & Clinical diagnosis & Spine & MRI corner sign & 0.44 & 0.96 & 11 & 0.58 \\
\hline \multicolumn{10}{|l|}{ Retrospective } \\
\hline Wick et $a l^{26}$ & 179 & AS (various) & Clinical diagnosis & SIJ & $\begin{array}{l}\text { ERO } \\
\text { BME }\end{array}$ & $\begin{array}{l}0.11 \\
0.35\end{array}$ & $\begin{array}{l}0.93 \\
0.78\end{array}$ & $\begin{array}{l}1.57 \\
1.59\end{array}$ & $\begin{array}{l}0.95 \\
0.83\end{array}$ \\
\hline Bennett et al ${ }^{2829}$ & 185 & SpA (DA, IBP, HC) & Clinical diagnosis & SIJ and spine & $\begin{array}{l}>3 \mathrm{RLS} \\
\text { Posterior BME lesion } \\
\geq 5 \mathrm{FRLS}\end{array}$ & $\begin{array}{l}0.33 \\
0.13 \\
0.22\end{array}$ & $\begin{array}{l}0.97 \\
0.99 \\
0.98\end{array}$ & $\begin{array}{l}12.4 \\
14.5 \\
12.6\end{array}$ & $\begin{array}{l}0.69 \\
0.87 \\
0.79\end{array}$ \\
\hline
\end{tabular}

The terms of the individual original publications have been used in the table.

$\mathrm{AS}$, ankylosing spondylitis; BME, bone marrow oedema; CIL, corner inflammatory lesion; DA, degenerative arthropathy; ERO, erosion; Fl, fatty infiltration; FRL, 'fatty Romanus' lesion; HC, healthy control; HLA27, human leucocyte antigen B27; IBP, inflammatory back pain; LIL, lateral segment inflammatory lesion; +LR, positive likelihood ratio; -LR, negative likelihood ratio; No., number of individuals included in the study; NSBP, non-specific back pain; RCT, randomised controlled trial; RL, 'Romanus' lesion; SE, sensitivity; SP, specificity; SI, sacroiliitis, SIJ, sacroiliac joints; SpA, spondyloarthritis.

Quality assessment is reported in online supplementary figure S6.2; of note risk of patient selection bias and applicability concerns with regard to the index test were high in $55 \%$ and $33 \%$ of included manuscripts, respectively.

Recommendation 3: monitoring disease activity in axial SpA

MRI of the SI joints and/or the spine may be used to assess and monitor disease activity in axial SpA, providing additional information on top of clinical and biochemical assessments. The decision on when to repeat MRI depends on the clinical circumstances. In general, short tau inversion recovery (STIR) sequences are sufficient to detect inflammation and the use of contrast medium is not needed.

Strength of recommendation: 9.2 (95\% CI 8.8 to 9.6)

Thirty-four studies evaluated the utility of MRI in monitoring disease activity in axSpA. ${ }^{20} 2148-79$ Table 3 summarises and pre-

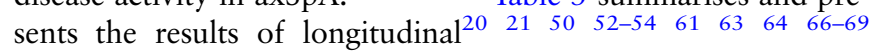
71737476 as well as cross-sectional ${ }^{51} 59607079$ studies evaluating correlation with accepted disease activity parameters (Bath Ankylosing Spondylitis Disease Activity Index (BASDAI), Ankylosing Spondylitis Disease Activity Score (ASDAS), C-reactive protein (CRP) and erythrocyte sedimentation rate (ESR)) or pain.

In addition, seven studies compared the utility of different MRI sequences (contrast-enhanced T1-weigthed (T1Gd) and STIR), for monitoring disease activity in axial SpA, ${ }^{48} 495356$ 576572 six of which reported high levels of agreement or correlation between the two sequences. 484953565765 A single longitudinal and two cross-sectional studies reported higher SE of STIR, ${ }^{49} 5365$ while a single longitudinal and two cross-sectional studies reported higher diagnostic confidence/reliability of the T1Gd-DPTA sequence. ${ }^{48} 4953$

Regarding frequency of spinal MRI examination, two longitudinal studies reported significant changes detected already at 6 or 12 weeks ${ }^{50}{ }^{72}$ with similar results for both STIR and T1Gd sequences. ${ }^{72}$ There is currently no evidence for how frequently MRI should be repeated for monitoring disease activity in axial SpA. Quality assessment is reported in online supplementary figure S6.3.

Recommendation 4: monitoring structural changes in axial SpA Conventional radiography of the SI joints and/or spine may be used for long-term monitoring of structural damage, particularly new bone formation, in axial SpA. If performed, it should not be repeated more frequently than every second year. MRI may provide additional information.

Strength of recommendation: 9.3 (95\% CI 8.8 to 9.8)

Twenty-three studies evaluated the utility of various imaging modalities in monitoring structural damage in axSpA. ${ }^{50} 63$ 70-72 80-97 Of 13 radiography studies, 10 reported correlation between radiographic changes and accepted measures of function (Bath Ankylosing Spondylitis Functional Index (BASFI), Bath Ankylosing Spondylitis Metrology Index (BASMI), metrological measures (chest expansion, occiput-to-wall distance, finger-to-floor distance, tragus-wall distance, Schober's test, spinal flexion, cervical rotation)) (table 4). ${ }^{63} 81-83$ 85-8793 9496

Six studies compared various spine radiography scoring methods (Bath Ankylosing Spondylitis Radiology Index (BASRI), Stoke Ankylosing Spondylitis Spinal Score (SASSS), modified Stoke Ankylosing Spondylitis Spinal Score (mSASSS), Berlin X-ray score, Radiographic Ankylosing Spondylitis Spinal Score (RASSS)), ${ }^{83} 84 \quad 8792 \quad 9396$ of which two reported mSASSS being superior to BASRI and SASSS. ${ }^{93} 96$ Baraliakos et $a l^{83}$ reported the RASSS method, which includes the thoracic segment, superior to mSASSS, while Ramiro et $a l^{92}$ reported no advantage of RASSS over mSASSS. Taylor et al $l^{95}$ reported correlation between CT changes and QSS in the SI joint. 
Table 3 Recommendation 3: summary of studies on the use of MRI in monitoring disease activity in axial spondyloarthritis

\begin{tabular}{|c|c|c|c|c|c|c|c|c|}
\hline \multirow[b]{2}{*}{ Studies } & \multirow[b]{2}{*}{ No. } & \multirow[b]{2}{*}{ Region } & \multirow[b]{2}{*}{ MRI scoring method } & \multicolumn{5}{|c|}{ Correlation } \\
\hline & & & & ASDAS & BASDAI & CRP & ESR & Pain \\
\hline \multicolumn{9}{|l|}{ Longitudinal/RCT } \\
\hline Marzo-Ortega et al ${ }^{20}$ & 76 & Spine & LEEDS & - & NS & NS & - & NS \\
\hline Oostveen et $a l^{21}$ & 25 & SIJ & $\mathrm{mNY}$ & & & OR 2.1 & OR 2.1 & OR 1.2 \\
\hline Baraliakos et $a l^{50}$ & 40 & Spine & ASspiMRI-a & - & NS & NS & NS & - \\
\hline Bonel et $a l^{52}$ & 28 & Spine & ASspiMRI-a & - & 0.41 & - & - & - \\
\hline Braun et $a l^{53}$ & 20 & Spine & ASspiMRI-a/c & - & $0.49-0.6$ & - & - & - \\
\hline Braun et $a l^{54}$ & 98 & Spine & ASspiMRI-a & 0.35 & NS & 0.4 & - & NS \\
\hline Lambert $2007^{61}$ & 82 & Spine/SIJ & SPARCC & - & NS & $p=0.018$ & - & NS \\
\hline Machado et $a l^{63}$ & 221 & Spine & ASspiMRI-a & 0.14 & NS & - & - & - \\
\hline Machado et $a l^{64}$ & 221 & Spine & ASspiMRI-a & 0.23 & NS & 0.32 & - & - \\
\hline Maksymowych et al ${ }^{66}$ & 68 & Spine & SPARCC & - & NS & $0.65-0.68$ & - & NS \\
\hline Maksymowych et $a l^{67}$ & 36 & Spine & SPARCC & - & NS & 0.45 & 0.44 & - \\
\hline Marzo-Ortega et al ${ }^{68}$ & 42 & Spine/SIJ & LEEDS & - & $p=0.04$ & - & - & - \\
\hline Pedersen et $a l^{69}$ & 82 & Spine/SIJ & Berlin & $0.46 / 0.31$ & $-0.41 /-0.31$ & NS & - & - \\
\hline Puhakka et al ${ }^{71}$ & 34 & SIJ & BME & - & NS & - & - & - \\
\hline Rudwaleit et $a l^{73}$ & 62 & Spine/SIJ & Berlin & - & NS & NS & NS & NS \\
\hline Sieper et $a l^{74}$ & 20 & Spine & ASspiMRI-a & - & 0.5 & NS & NS & - \\
\hline Song et $a l^{76}$ & 76 & Spine/SIJ & ASspiMRI-a/Berlin & $p=0.04$ & - & NS & - & - \\
\hline Visvanathan et al ${ }^{77}$ & 279 & Spine & ASspiMRI-a & - & - & $\mathrm{p}<0.001$ & - & - \\
\hline \multicolumn{9}{|l|}{ Cross-sectional/case-control } \\
\hline Blachier $2013^{51}$ & 648 & Spine/SIJ & Dichotomous & - & - & - & - & aOR $1.71-2.86$ \\
\hline Goh et $a P^{55}$ & 34 & Spine & ASspiMRI-a & - & NS & NS & NS & - \\
\hline Kiltz et $a l^{59}$ & 100 & Spine/SIJ & Berlin & NS & NS & 0.22 & - & - \\
\hline Konca et al ${ }^{60}$ & 50 & Spine & ASspiMRI-a & 0.37 & NS & 0.33 & 0.39 & - \\
\hline Puhakka et al ${ }^{70}$ & 41 & SIJ & BME enhancement & - & NS & - & - & - \\
\hline Weber et al ${ }^{79}$ & 197 & ACW & Dichotomous & - & - & - & - & к $0.21-0.33$ \\
\hline
\end{tabular}

Five studies reported correlation between changes over time in MRI and radiography and/or CT parameters of structural damage, ${ }^{71} 8488-90$ while Puhakka et $a l^{91}$ found MRI and CT are superior to radiography. A single study reported correlation between spinal MRI and metrological measures, ${ }^{97}$ while two reported no correlation. ${ }^{70} 91$ One study reported correlation between MRI changes and BASMI, ${ }^{88}$ whereas two studies reported no correlation with BASFI. ${ }^{70} 97$ Akgul et al ${ }^{80}$ reported that fatty infiltration of the paraspinal muscles on MRI correlates with metrological measures. Regarding the frequency of MRI examinations for the monitoring of structural changes under treatment with a tumour necrosis factor (TNF) inhibitor, Rudwaleit et $a l^{72}$ reported no significant spinal or SI joint changes after 24 weeks, while Baraliakos et al reported significant deterioration in the mean Ankylosing Spondylitis spinal MRI chronicity score (ASspiMRI-c) in the placebo group at 48 weeks. ${ }^{50}$ There is currently no evidence whether and if so how frequently MRI should be repeated for the monitoring of structural changes in axial SpA. Quality assessment is reported in online supplementary figure S6.4; of note risk of patient selection bias and applicability concerns with regard to patient selection were high in $43 \%$ and $30 \%$ of included manuscripts, respectively.

Recommendation 5: monitoring disease activity in peripheral SpA US and MRI may be used to monitor disease activity (particularly synovitis and enthesitis) in peripheral SpA, providing additional information on top of clinical and biochemical assessments. The decision on when to repeat US/MRI depends on the clinical circumstances. US with high-sensitivity colour or power Doppler is sufficient to detect inflammation and the use of US contrast medium is not needed.

Strength of recommendation: 9.3 (95\% CI 8.9 to 9.7 )

Fifteen studies evaluated the utility of various imaging modalities in monitoring disease activity in $\mathrm{pSpA},{ }^{39} 40^{98-110}$ of which 10 investigated GSUS/PDUS for the assessment of entheses (8 on multiple entheses, 2 on the Achilles tendon). Out of the 10 studies investigating GSUS/PDUS, only a single study was longitudinal, ${ }^{98}$ while the remaining 9 were cross-sectional. ${ }^{39} 40$ 99-105 A single study reported correlation with BASDAI, ${ }^{99}$ while four reported no correlation. ${ }^{98} 100-102$ Aydin et al ${ }^{100}$ reported correlation between grey-scale entheseal changes of the Achilles tendon and CRP, while five studies reported no correlation with CRP and/or ESR. ${ }^{98}$ 101-104 Hamdi et $a l^{99}$ reported correlation between pain and power Doppler entheseal changes of the lower limb entheses, while Kiris et $a l^{102}$ reported no correlation between PD and axial entheses.

Two studies reported correlation with swollen or tender joint count, $^{39} 104$ while a single study reported no correlation. ${ }^{40}$ Hamdi et $a l^{99}$ reported correlation with clinical enthesis indices (Maastricht Ankylosing Spondylitis Score, Spondyloarthritis Research Consortium of Canada (SPARCC) Enthesitis Index), while two studies reported no correlation. ${ }^{39}$ 98 Two studies reported discrepancies in abnormal entheses detected by US versus clinical examination. ${ }^{40} 105$ 
Table 4 Recommendation 4: summary of studies on the use of radiography in monitoring structural changes in axial spondyloarthritis

\begin{tabular}{|c|c|c|c|c|c|c|c|}
\hline \multirow[b]{2}{*}{ Studies } & \multirow[b]{2}{*}{ No. } & \multirow[b]{2}{*}{ Region } & \multirow[b]{2}{*}{ X-ray scoring method } & \multicolumn{4}{|l|}{ Correlation } \\
\hline & & & & BASFI & BASMI & Metrological measures & СТ \\
\hline \multicolumn{8}{|l|}{ Longitudinal/RCT } \\
\hline Machado et al ${ }^{63}$ & 214 & Spine & mSASSS & $0.18 ; p=0.008$ & $0.59 ; p<0.001$ & - & - \\
\hline Averns et $\left.a\right|^{81}$ & 53 & Spine & SASSS & - & - & $\begin{array}{l}-0.396, p<0.01 \text { (CE) } \\
0.503, p<0.001 \text { (OWD) } \\
0.351, p<0.02 \text { (FFD) } \\
-0.690, p<0.0001 \text { (Schober) } \\
-0.717, p<0.0001 \text { (total spinal movement) }\end{array}$ & - \\
\hline Baraliakos et $\left.a\right|^{82}$ & 82 & Spine & mSASSS & NS & $0.49-0.59 ; p=0.01$ & - & - \\
\hline Baraliakos et $a^{83}$ & 80 & Spine & mSASSS & - & 0.49 & NS & - \\
\hline Creemers et $a /^{85}$ & 50 & Spine & mSASSS & - & - & $\mathrm{p}=0.05-0.0005(\mathrm{CE}, \mathrm{OWD}, \mathrm{SF})$ & - \\
\hline Salaffi et a $a^{93}$ & 95 & Spine & mSASSS & $\mathrm{p}=0.02$ & $p=0.01$ & - & - \\
\hline Taylor et al ${ }^{94}$ & 70 & Spine/SIJ & Semi-quantitative & - & - & $-0.40 ; p<0.05$ (SF) & $\begin{array}{l}0.52 ; \mathrm{p}<0.01 \text { (spine) } 0.75 ; \\
\mathrm{p}<0.001 \text { (SIJ) }\end{array}$ \\
\hline Wanders et $a l^{96}$ & 133 & Spine/SIJ & $\begin{array}{l}\text { mSASSS } \\
\text { SASSS } \\
\text { BASRI }\end{array}$ & 0.41 & - & $\begin{array}{l}-0.77 \text { (SF) } \\
0.65 \text { (OWD) } \\
-0.76 \text { (mSchober) }\end{array}$ & - \\
\hline \multicolumn{8}{|c|}{ Cross-sectional/case-control } \\
\hline Lee et $\left.a\right|^{86}$ & 39 & Spine & BASRI & - & - & - & $0.53-0.73(p<0.001)$ \\
\hline Lubrano et $a l^{87}$ & 77 & Spine & $\begin{array}{l}\text { BASRI } \\
\text { mSASSS }\end{array}$ & NS & $0.47 ; p<0.001$ & $\begin{array}{l}0.49, \mathrm{p}<0.001 \text { (CR) } \\
0.34, \mathrm{p}<0.01 \text { (TWD) } \\
0.49, \mathrm{p}<0.001 \text { (OWD) } \\
-0.24, \mathrm{p}<0.05 \text { (mSchober) } \\
0.37, \mathrm{p}<0.01 \text { (FFD) }\end{array}$ & - \\
\hline
\end{tabular}

Four longitudinal ${ }^{106-109}$ and a single cross-sectional ${ }^{110}$ study evaluated the utility of MRI in monitoring disease activity in $\mathrm{pSpA}$ with three longitudinal studies reporting the psoriatic arthritis MRI score (PsAMRIS) and rheumatoid arthritis MRI score performing well regarding SE to change. ${ }^{106-108}$ Tan et al found no correlation between BME (as scored by PsAMRIS) and clinical disease activity measures in a cross-sectional study. ${ }^{110}$ There is currently no evidence whether and if so how frequently US and/or MRI should be repeated for the monitoring of disease activity in peripheral SpA. Quality assessment is reported in online supplementary figure S6.5; of note patient selection bias was high in $47 \%$ of included manuscripts.

Recommendation 6: monitoring structural changes in peripheral $S p A$

In peripheral $\mathrm{SpA}$, if the clinical scenario requires monitoring of structural damage, then conventional radiography is recommended. MRI and/or US might provide additional information.

Strength of recommendation: 8.9 (95\% CI 8.4 to 9.4)

Seven studies evaluated the utility of conventional radiography (CR) to monitor structural changes in $\mathrm{pSpA},{ }^{101} 102$ 111-115 with one study also evaluating PDUS ${ }^{102}$ and an additional study evaluating MRI. ${ }^{110}$ Among the studies assessing the utility of radiography, two reported correlation with the functional indices Health Assessment Questionnaire and/or Arthritis Impact Measurement Scales. ${ }^{114} 115$ A longitudinal study on 74 patients with PsA reported correlation between clinical joint deformity, typical radiographic changes in PsA and the PsA-modified Sharp score. ${ }^{114}$ A case-control study on 98 patients with ReA reported correlation between radiographic condylar erosions of the temporomandibular joint and patient-reported outcomes. ${ }^{112} \mathrm{~A}$ crosssectional study on 60 patients with AS reported correlation between BASFI and both radiographic and sonographic signs of enthesitis, ${ }^{102}$ while a cross-sectional study on 44 patients with $\mathrm{SpA}$ reported correlation between the $\mathrm{SpA}$ tarsal radiographic index and the Glasgow Ultrasound Enthesitis Score, but no correlation between the radiographic index and BASMI or BASRI. ${ }^{101}$ Finally, Tan et al ${ }^{110}$ reported correlation between MRI erosions/BME and CR erosions/joint space narrowing in 28 patients with PsA. Quality assessment is reported in online supplementary figure S6.6; of note risk of patient selection bias was high in $50 \%$ of included manuscripts. There is currently no evidence whether and if so how frequently US and/or MRI should be repeated for the monitoring of structural changes in peripheral SpA.

Recommendation 7: predicting outcome/severity in axial SpA In patients with $\mathrm{AS}^{*}$ (not non-radiographic axial $\mathrm{SpA}$ ), initial conventional radiography of the lumbar and cervical spine is recommended to detect syndesmophytes, which are predictive of development of new syndesmophytes. MRI (vertebral corner inflammatory or fatty lesions) may also be used to predict development of new radiographic syndesmophytes.

*That is, radiographic axial spondyloarthritis.

Strength of recommendation: 9.0 (95\% CI 8.5 to 9.5 )

Seventeen publications were included. ${ }^{19} \quad 81 \quad 82$ 116-129 All studies evaluating radiography reported that baseline radiographic change (syndesmophytes) predicts radiographic progression in AS. ${ }^{82} 116118122126129$ Baraliakos et al reported that syndesmophytes/ankylosis, rather than erosion or sclerosis, were the features most frequently showing progression in AS. ${ }^{116}$ Maksymowych et $a l^{122}$ found that high baseline mSASSS (cut-off of 10 units; OR 18.6) was an independent predictor of 2-year progression in AS. 
Six studies reported correlation between CILs or vertebral edge inflammation on MRI and subsequent radiographic syndesmophyte formation in patients with AS. ${ }^{117} 119120123124128$ Madsen $e t a l^{121}$ reported correlation of baseline inflammation and subchondral fatty marrow deposition on MRI with radiographic progression in the SI joint of patients with AS.

In a 2-year longitudinal study, Pedersen et al ${ }^{124}$ found that new syndesmophytes develop more frequently from vertebral corners where a CIL had completely resolved on follow-up, and that no single vertebral corner evolved into a new syndesmophyte where a CIL was persistently observed on both baseline and follow-up MRI. Along the same line, a 2-year longitudinal study of patients with axSpA/AS revealed an association between decreasing inflammation in the SI joint and the concomitant development of new syndesmophytes (OR 12.48). ${ }^{125}$ In a 1 -year longitudinal study, Song et $a l^{127}$ presented a significant relationship between the disappearance of inflammation and the appearance of fatty lesions in the spine of patients with axSpA. Moreover, Baraliakos et $a l^{119}$ showed that both spinal inflammation and fatty degeneration were associated with later syndesmophyte development but fatty degeneration showed the highest risk in AS. In contrast, a retrospective analysis of 100 patients with AS, inflammation (OR 5.8) emerged as a more significant predictor of new syndesmophytes than did fat infiltration (OR 1.9). ${ }^{120}$ Finally, Bennett $e$ al $^{19}$ reported no association between baseline BME on lumbar spine MRI and mSASSS progression after 8 years in patients with AS.

Averns $e t a l^{81}$ reported correlation between baseline QSS values and radiographic progression in the spine at follow-up (median: 9 years) in patients with AS. Quality assessment is reported in online supplementary figure S6.7.

Recommendation 8: predicting treatment effect in axial SpA

Extensive MRI inflammatory activity (BME), particularly in the spine in patients with AS, might be used as a predictor of good clinical response to anti-TNF-alpha treatment in axial SpA. Thus, MRI might aid in the decision of initiating anti-TNFalpha therapy, in addition to clinical examination and CRP.

Strength of recommendation: 8.9 (95\% CI 8.3 to 9.5 )

A total of three studies were included. A longitudinal study of 62 patients with AS under treatment anti-TNF-alpha biologics reported a positive likelihood ratio of 6.7 for achieving BASDAI50 response in patients with a Berlin MRI spine score $>11$, while the absence of active inflammatory lesions in the spine was highly predictive of not achieving BASDAI50. Only a trend was found for the MRI SI joint score. ${ }^{73}$ An RCT of 185 patients with non-radiographic axial SpA reported that a baseline SPARCC MRI score $\geq 2$ for either the SI joint or the spine was associated with better response after 12 weeks of adalimumab. ${ }^{75}$ An RCT including 40 human leucocyte antigen B27 (HLAB27)-positive patients with MRI sacroiliitis found no significant difference in BASDAI changes between patients with mild versus moderate/severe MRI SI joint BME at baseline. ${ }^{130}$ Quality assessment is reported in online supplementary figure S6.8; of note risk of patient selection bias, as well as of flow and timing and applicability concerns, was each high in 33\% of included manuscripts.

Recommendation 9: spinal fracture

When spinal fracture in axial SpA is suspected, conventional radiography is the recommended initial imaging method. If conventional radiography is negative, CT should be performed. MRI is an additional imaging method to CT, which can also provide information on soft tissue lesions.

Strength of recommendation: 9.3 (95\% CI 8.9 to 9.7)
Although no study met the inclusion criteria for this recommendation, two studies selected for full-text review were presented to the taskforce as they could provide some evidence (quality assessment however was not performed). The first study included 11 patients with AS and neurological symptoms after trauma to the neck region. CT and MRI detected all fractures while radiography detected $82 \%$ of them. Soft tissue injuries were detected in four patients, only by MRI. ${ }^{131}$ The second study included 199 patients from the general population with suspected cervical spine injury. Twenty-one acute fractures were detected in 14 patients. Weighted average SE to detect acute fractures for MRI and radiography were 0.43 (95\% CI 0.21 to 0.66 ) and 0.48 (95\% CI 0.30 to 0.65$)$, respectively. In contrast, weighted average SE to detect soft tissue injuries for MRI and radiography were 0.55 (95\% CI 0.39 to 0.70$)$ and $0.07(95 \%$ CI 0.02 to 0.13 ), respectively. ${ }^{132}$ In addition to its utility in imaging soft tissue, MRI allows the direct visualisation of the spinal cord and thus direct evaluation of spinal cord injuries.

Recommendation 10: osteoporosis

In patients with axial SpA without syndesmophytes in the lumbar spine on conventional radiography, osteoporosis should be assessed by hip DXA and anterior-posterior (AP)-spine DXA. In patients with syndesmophytes in the lumbar spine on conventional radiography, osteoporosis should be assessed by hip DXA, supplemented by either spine DXA in lateral projection or possibly quantitative CT (QCT) of the spine.

Strength of recommendation: 9.4 (95\% CI 9.0 to 9.8$)$

A total of 42 studies were included, ${ }^{133-174}$ while one additional study that did not meet the inclusion criteria but provided some evidence was also shown to the taskforce. ${ }^{175}$ Only one study compared the diagnostic utility between two different techniques for detecting osteoporosis in SpA. This reported moderate SE $(0.50-0.75)$ and SP $(0.67-0.75)$ for quantitative US compared with DXA. ${ }^{133}$ Three studies reported no additional value of quantitative US compared with DXA ${ }^{134-136}$ while three studies compared QCT to DXA and reported that in patients with advanced AS osteoporosis is more frequently detected by QCT of the spine than using DXA of the spine $^{137} 175$ or the hip region. ${ }^{138}$

Moreover, 37 studies (32 in axSpA and 6 in PsA) provided data on the site for performing DXA. ${ }^{139-173}$ In axSpA, 20 studies compared DXA at different sites for distinguishing between patients with AS and controls. Fifteen of these studies compared the $\mathrm{AP} /$ posterior-anterior $(\mathrm{PA})$ projection at the spine versus the hip region but the results were inconsistent: six studies observed no differences, ${ }^{136}{ }^{139-143}$ eight reported results in favour of the hip ${ }^{135}{ }^{144-150}$ and one in favour of the spine. ${ }^{151}$ Three studies compared the AP/PA versus the lateral projection at the spine and all reported that the lateral projection differentiated better between AS and controls. ${ }^{145} 146149$ Only four studies compared forearm DXA with other regions, all of them reporting data in favour of spine or hip ${ }^{137142} 152153$ regions.

Furthermore, some studies also evaluated the possible influence of radiographic change, disease duration or disease activity in bone mineral density (BMD) determination at different regions (table 5). Most of the studies found the hip region being less influenced by radiographic change than the $\mathrm{AP} / \mathrm{PA}$ projection of the spine. ${ }^{137138} 142145147148154155156$ Two studies reported the lateral spine projection being less influenced by radiographic change than the $\mathrm{AP} / \mathrm{PA}$ projection. ${ }^{145} 157$ Moreover, the majority of the studies found a positive correlation between $\mathrm{BMD}$ and disease duration with $\mathrm{AP} / \mathrm{PA}$ projection of the spine while no correlation was found with the lateral projection or at hip. However, most of the studies did not observe 
Table 5 Recommendation 10: summary of studies evaluating different localisations to perform dual-energy X-ray absorptiometry in patients with axial spondyloarthritis

\begin{tabular}{|c|c|c|c|}
\hline \multirow{3}{*}{$\begin{array}{l}\text { (A) } \\
\text { Study } \\
\mathrm{N}=11\end{array}$} & \multirow[b]{3}{*}{ No. } & \multirow{2}{*}{\multicolumn{2}{|c|}{$\begin{array}{l}\text { Radiographic damage } \\
\text { (syndesmophytes/BASRI spine) } \\
\text { Results in favour of }\end{array}$}} \\
\hline & & & \\
\hline & & AP/PA spine & Hip \\
\hline Devogelaer et $a l^{137}$ & 70 & & $x$ \\
\hline Karberg $2005^{138}$ & 103 & & $x$ \\
\hline Jun $2006^{140}$ & 68 & ND & ND \\
\hline Mullaji $1994^{142}$ & 33 & & $x$ \\
\hline Gilgil $2005^{145}$ & 20 & & $x$ \\
\hline Muntean $2011^{147}$ & 44 & & $x$ \\
\hline Taylan $2012^{148}$ & 55 & & $x$ \\
\hline Vasdev $2001^{151}$ & 80 & ND & ND \\
\hline Baek $2005^{154}$ & 76 & & $x$ \\
\hline Сарасі 2003 & 73 & & $x$ \\
\hline Donelly $1994^{156}$ & 87 & & $x$ \\
\hline $\mathrm{N}=2$ & & AP/PA spine & Lateral spine \\
\hline Gilgil $2005^{145}$ & 20 & & $\mathrm{x}$ \\
\hline Klingberg $2012^{157}$ & 204 & & $x$ \\
\hline
\end{tabular}

(B)

\begin{tabular}{|c|c|c|c|}
\hline \multirow{2}{*}{$\begin{array}{l}\text { Study } \\
\mathrm{N}=12\end{array}$} & \multirow[b]{2}{*}{ No. } & \multicolumn{2}{|c|}{$\begin{array}{l}\text { Correlation between BMD and } \\
\text { disease duration }\end{array}$} \\
\hline & & AP/PA spine & Hip \\
\hline Arends $2011^{170}$ & 198 & $r=0.34$ & NS \\
\hline El Magahroui $1999^{173}$ & 80 & $r=0.23$ & NS \\
\hline Gilgil $2005^{145}$ & 20 & $r=0.52$ & NS \\
\hline Grazio $2012^{158}$ & 80 & $r=0.05$ & $r=-0.361$ \\
\hline Jansen et $\mathrm{al}^{133}$ & 50 & No & $r=0.35$ \\
\hline Meirelles $1999^{141}$ & 30 & $r=0.65$ & NS \\
\hline Mermerci $2010^{146}$ & 100 & $r=0.25$ & $r=-0.20$ \\
\hline Muntean $2011^{147}$ & 44 & NS & NS \\
\hline Speden et $a l^{135}$ & 66 & NS & NS \\
\hline Taylan $2012^{148}$ & 55 & $r=0.30$ & NS \\
\hline van der Weijden $2011^{160}$ & 130 & NS & NS \\
\hline Vasdev $2011^{151}$ & 80 & NS & NS \\
\hline $\mathrm{N}=2$ & & AP/PA spine & Lateral spine \\
\hline Gilgil $2005^{145}$ & 20 & $r=0.52$ & NS \\
\hline Memerci $2010^{146}$ & 100 & $r=0.25$ & NS \\
\hline
\end{tabular}

(C)

\begin{tabular}{|c|c|c|c|}
\hline \multirow{2}{*}{$\begin{array}{l}\text { Study } \\
\mathrm{N}=9\end{array}$} & \multirow[b]{2}{*}{ No. } & \multicolumn{2}{|c|}{$\begin{array}{l}\text { Correlation between BMD and } \\
\text { disease activity parameters } \\
\text { (ASDAS, BASDAl, CRP, ESR) }\end{array}$} \\
\hline & & AP/PA spine & Hip \\
\hline Frediani et $a l^{134}$ & 186 & NS & NS \\
\hline Grazio $2012^{158}$ & 80 & $r=-0.30$ & $\mathrm{r}=-0.22$ \\
\hline Mermerci $2010^{146}$ & 100 & $r=-0.24$ & $r=-0.24$ \\
\hline Mullaji $1994^{142}$ & 33 & NS & NS \\
\hline Muntean $2011^{147}$ & 44 & NS & NS \\
\hline Park $2008^{159}$ & 35 & NS & $r=-0.49$ \\
\hline Taylan $2012^{148}$ & 55 & NS & NS \\
\hline van der Weijden $2011^{160}$ & 130 & NS & NS \\
\hline Vasdev $2011^{151}$ & 80 & NS & NS \\
\hline$N=1$ & & AP/PA spine & Lateral spine \\
\hline
\end{tabular}

The Pearson test for rank correlation is used for test of correlation, values are correlation coefficients $(r)$.

AP, anterior-posterior; ASDAS, Ankylosing Spondylitis Disease Activity Score; BASDAI, Bath Ankylosing Spondylitis Disease Activity Score; BASRI, Bath Ankylosing

Spondylitis Radiology Index; BMD, bone mineral density; CRP, C-reactive protein; ESR, erythrocyte sedimentation rate; ND, no statistically significant differences; NS, not statistically significant; PA, posterior-anterior. correlation with $\mathrm{AP} / \mathrm{PA}$ projection of the spine or at hip. $^{135} 141$ 146-148 $151 \quad 158-160$ In patients with PsA, published data are scarce. Three studies compared the ability of AP/PA DXA of the spine with DXA of the hip to distinguish between patients with PsA and controls but the results were not consistent. $^{134} 161162$ In patients with PsA, no correlation was observed between BMD detected by AP/PA DXA of the spine or the hip with disease duration ${ }^{134} 163$ or with disease activity. ${ }^{134} 164$

\section{Box 1 Future research agenda}

1. To further investigate which imaging findings (imaging modality, anatomical location and type of pathology) provides the best clinical utility for early and accurate diagnosis of SpA.

2. To further investigate which imaging findings (imaging modality, anatomical location and type of pathology) are best for monitoring peripheral and axial disease activity and structural damage in $\mathrm{SpA}$ in clinical practice.

3. To further investigate which imaging findings (imaging modality, anatomical location and type of pathology) best predict the disease course (structural progression, pain, functional ability, health-related quality of life) and treatment response in SpA.

4. To further investigate which imaging approaches best identify and monitor specific SpA-related features (such as enthesitis, dactylitis, synovitis and tenosynovitis, at different locations) in clinical practice.

5. To further investigate the spatial and temporal relation between different imaging findings (imaging modality, anatomical location and type of pathology) providing further insight into the disease process of SpA, which may inform future clinical management of SpA.

6. To investigate the importance of subclinical (detected only on imaging) axial and peripheral inflammation (including bone marrow oedema, synovitis, tenosynovitis and/or enthesitis), and if possible to identify thresholds to guide intervention. Subsequently to investigate the benefits (eg, on functional ability and quality of life) of incorporating such thresholds into treat-to-target strategies.

7. To investigate new and/or alternative technical options to existing imaging technologies (US: eg, 3D/4D-transducers, Doppler quantification, elastosonography; MRI: eg, whole-body MRI, diffusion-weighted MRI and dynamic contrast-enhanced MRI with automated reading) as well as new imaging modalities (eg, optical imaging, new nuclear medicine techniques) of potential use in SpA in clinical practice.

8. To further evaluate specific areas/joints to be assessed, timing of assessment(s) and the evaluation system to be employed in order to optimise the role of modern imaging modalities in the diagnosis, prognosis and outcome measurement of SpA.

9. To investigate which imaging approach provides the best clinical utility for diagnosing spinal fractures, and the consequences thereof.

10. To investigate which imaging approach provides the best clinical utility for diagnosis and monitoring of osteoporosis in SpA.

SpA, spondyloarthritis; US, ultrasound; 3D, three-dimensional; $4 \mathrm{D}$, four-dimensional. 
Finally, only four longitudinal studies assessed BMD over time to monitor osteoporosis in patients with SpA. ${ }^{165-168}$ In these studies, changes in BMD were observed after 1-2 years, especially in patients with active disease. Quality assessment is reported in online supplementary figure S6.9; of note risk of index test and reference standard bias were high in $86 \%$ and $88 \%$ of included manuscripts, respectively.

\section{DISCUSSION}

These are the first recommendations produced by a EULAR taskforce on the use of imaging in SpA clinical practice. The group combined research-based evidence and expert opinion through a translational process among the experts from the presented literature-derived evidence to the final wording. Recommendations were primarily based on available research evidence with the exception of recommendation 9, which, lacking available data, was reliant on expert opinion. Finally, experts scored the SOR for each recommendation using data from the quality assessment.

We acknowledge that there is still a large amount of research required to optimise the use of imaging tools in the routine clinical practice of SpA. ${ }^{176}$ We have summarised the most important topics for future research according to currently available evidence and clinical practice in box 1 . These recommendations will likely need to be revisited in the future when important new evidence becomes available. ${ }^{12}$

In summary, we have developed 10 recommendations on various aspects of imaging in $\mathrm{SpA}$. These are based on the best available evidence and clinical expertise supported by an international panel of experts. We aimed to produce recommendations that are practical and valuable in daily practice for rheumatologists, radiologists and general practitioners.

\footnotetext{
Author affiliations

${ }^{1}$ Division of Rheumatology, Medical University of Vienna, Vienna, Austria

${ }^{2}$ Department of Rheumatology, Leiden University Medical Center, Leiden, The Netherlands

${ }^{3}$ University Hospital La Paz, Madrid, Spain

${ }^{4}$ Copenhagen Center for Arthritis Research, Center for Rheumatology and Spine Diseases, Copenhagen University Hospital at Glostrup, Copenhagen, Denmark ${ }^{5}$ Public Health Department, Ambroise Paré Hospital, Boulogne-Billancourt, France ${ }^{6}$ Department of Rheumatology, Ambroise Paré Hospital, Boulogne-Billancourt, France ${ }^{7}$ Rheumazentrum Ruhrgebiet, Herne, Germany

${ }^{8}$ Department of Rheumatology, Copenhagen University Hospital at Gentofte, Copenhagen, Denmark

${ }^{9}$ Department of Radiology, Aarhus University Hospital, Aarhus, Denmark

${ }^{10}$ Department of Rheumatology, Hospital General Universitario Gregorio Marañón, Madrid, Spain

${ }^{11}$ Department of Biomedical Imaging and Image-guided Therapy, Medical University of Vienna, Vienna, Austria

${ }^{12}$ King Christian 10th Hospital for Rheumatic Diseases, Gråsten, Denmark

${ }^{13}$ Department of Radiology, Karolinska University Hospital, Stockholm, Sweden

${ }^{14}$ Department of Rheumatology, Università Politecnica delle Marche, Ancona, Italy

${ }^{15}$ NIHR Leeds Musculoskeletal Biomedical Research Unit, Leeds Institute of

Rheumatic and Musculoskeletal Medicine, University of Leeds, Leeds, UK

${ }^{16}$ Department of Rheumatology, Charité Universitätsmedizin, Berlin, Germany

${ }^{17}$ Department of Rheumatology and Immunology, University of Erlangen-Nuremberg, Erlangen, Germany

${ }^{18}$ Musculoskeletal Statistics Unit, Department of Rheumatology, The Parker Institute, Copenhagen University Hospital, Bispebjerg and Frederiksberg, Copenhagen, Denmark
}

Contributors PM and VN-C performed the literature review with help from ST, PA and PAB. PM and VN-C produced drafts of the manuscript with advice from OM and LT. All authors were involved in the conception of the study, in the analysis and interpretation of data, in the production of the recommendations and have reviewed the final manuscript.

Competing interests PM: consultancy/speaker fees: AbbVie, BMS, GE, Janssen, MSD, Pfizer, Roche, UCB; VN-C: consultancy/research grants: AbbVie, BMS, MSD, Novartis, Pfizer, Roche, UCB; LT: consultancy/speaker fees: AbbVie, GE, MSD, Roche,
UCB; PA: none; DvdH: consultancy/research grants: AbbVie, Amgen, AstraZeneca, Augurex, BMS, Boehringer Ingelheim, Celgene, Centocor, Chugai, Covagen, Daiichi, Eli-Lilly, Galapagos, GSK, Janssen Biologics, Merck, Novartis, Novo-Nordisk, Otsuka, Pfizer, Roche, Sanofi-Aventis, UCB, Vertex, Director of Imaging Rheumatology International; MAD'A: consultancy/speaker fees: AbbVie, BMS, MSD, Novartis, Pfizer, UCB; XB: consultancy/speaker fees: AbbVie, Amgen, Boehringer Ingelheim, BMS, Celgene, Centocor, Chugai, Janssen, MSD, Novatis, Pfizer, Sandoz, UCB; SJP: consultancy/speaker fees: AbbVie, MSD, Pfizer, Roche, UCB, Wyeth; research grants: AbbVie, MSD; AGJ: none; EN: research grants: MSD, Spanish Foundation of Rheumatology; speaker fees: Abbvie, BMS, ESAOTE, GE, Pfizer, Roche, UCB; CS-W: speaker fees: AbbVie, Eli-Lilly, Roche; UW: speaker fees: AbbVie, MSD; MCW: none; PACB: none; EF: speaker fees: Abbvie, BMS, MSD, UCB; PGC: consultancy/speaker fees: Abbvie, BMS, Janssen, Merck, Novartis, Pfizer, Roche; MR: consultancy: AbbVie, BMS; speaker fees: Chugai, MSD, Novartis, Pfizer, Roche, UCB; GS: none; JS: consultancy/speaker fees: Abbott, Janssen, Merck, Lilly, Novartis, Roche; research grants: Abbott, Merck, Pfizer; ST: speaker fees: AstraZeneca, Norpharma, Pfizer; research grants paid to institute: AbbVie, BMS, Mundipharma, Roche; HM-O: speaker fees/research grants: AbbVie, Celgene, Janssen, MSD, Novartis, Pfizer, UCB; MØ: research grant: Abbvie, Janssen, Merck; consultancy/speaker fees: Abbvie, BMS Boehringer Ingelheim, Celgene, Centocor, Eli-Lilly, GSK, Hospira, Janssen, Merck, Mundipharma, Novartis, Orion, Pfizer, Roche, Takeda, UCB.

Provenance and peer review Not commissioned; externally peer reviewed.

\section{REFERENCES}

1 van Tubergen A, Weber U. Diagnosis and classification in spondyloarthritis: identifying a chameleon. Nat Rev Rheumatol 2012;8:253-61.

2 Dougados $M$, van der Linden $S$, Juhlin $R$, et al. The European Spondylarthropathy Study Group preliminary criteria for the classification of spondylarthropathy. Arthritis Rheum 1991;34:1218-27.

3 Amor B, Dougados M, Mijiyawa M. Criteria of the classification of spondylarthropathies [French]. Rev Rhum 1990;57:85-9.

4 van der Linden S, Valkenburg HA, Cats A. Evaluation of diagnostic criteria for ankylosing spondylitis. A proposal for modification of the New York criteria. Arthritis Rheum 1984;27:361-8.

5 Khan MA, van der Linden SM. A wider spectrum of spondyloarthropathies. Semin Arthritis Rheum 1990;20:107-13.

6 Khan MA, van der Linden SM, Kushner I, et al. Spondylitic disease without radiological evidence of sacroiliitis in relatives of HLA-B27 positive patients. Arthritis Rheum 1985;28:40-3.

7 Rudwaleit $M$, van der Heijde $D$, Landewé $R$, et al. The development of Assessment of SpondyloArthritis international Society classification criteria for axial spondyloarthritis (part II): validation and final selection. Ann Rheum Dis 2009;68:777-83.

8 Rudwaleit M, van der Heijde D, Landewé R, et al. The Assessment of SpondyloArthritis International Society classification criteria for peripheral spondyloarthritis and for spondyloarthritis in general. Ann Rheum Dis 2011;70:25-31.

9 Braun J, Bollow M, Eggens U, et al. Use of dynamic magnetic resonance imaging with fast imaging in the detection of early and advanced sacroiliitis in spondylarthropathy patients. Arthritis Rheum 1994;37 1039-45.

10 Whiting PF, Rutjes AW, Westwood ME, et al. QUADAS-2: a revised tool for the quality assessment of diagnostic accuracy studies. Ann Intern Med 2011;155:529-36.

11 McNally E, Keogh C, Galvin R, et al. Diagnostic accuracy of a clinical prediction rule (CPR) for identifying patients with recent-onset undifferentiated arthritis who are at a high risk of developing rheumatoid arthritis: A systematic review and meta-analysis. Semin Arthritis Rheum 2014;43:498-507.

12 Dougados M, Betteridge N, Burmester GR, et al. EULAR standardised operating procedures for the elaboration, evaluation, dissemination, and implementation of recommendations endorsed by the EULAR standing committees. Ann Rheum Dis 2004;63:1172-6.

13 Shekelle PG, Woolf $\mathrm{SH}$, Eccles $M$, et al. Clinical guidelines: developing guidelines. BMJ 1999;318:593-6.

14 Blum U, Buitrago-Tellez C, Mundinger A, et al. Magnetic resonance imaging (MRI) for detection of active sacroiliitis - a prospective study comparing conventional radiography, scintigraphy, and contrast enhanced MRI. J Rheumatol 1996:23:2107-15

15 Devauchelle-Pensec V, D'Agostino MA, Marion J, et al. Computed tomography scanning facilitates the diagnosis of sacroiliitis in patients with suspected spondylarthritis: results of a prospective multicenter French cohort study. Arthritis Rheum 2012;64:1412-19.

16 Goie The HS, Steven MM, van der Linden SM, et al. Evaluation of diagnostic criteria for ankylosing spondylitis: a comparison of the Rome, New York and modified New York criteria in patients with a positive clinical history screening test for ankylosing spondylitis. Br J Rheumatol 1985;24:242-9. 
17 van Tubergen A, Heuft-Dorenbosch L, Schulpen G, et al. Radiographic assessment of sacroiliitis by radiologists and rheumatologists: does training improve quality? Ann Rheum Dis 2003:62:519-25.

18 Geijer M, Göthlin GG, Göthlin JH. The clinical utility of computed tomography compared to conventional radiography in diagnosing sacroiliitis. A retrospective study on 910 patients and literature review. J Rheumatol 2007;34:1561-5.

19 Bennett AN, McGonagle D, O'Connor P, et al. Severity of baseline magnetic resonance imaging-evident sacroiliitis and HLA-B27 status in early inflammatory back pain predict radiographically evident ankylosing spondylitis at eight years. Arthritis Rheum 2008;58:3413-18.

20 Marzo-Ortega H, McGonagle D, O'Connor $\mathrm{P}$, et al. Baseline and 1-year magnetic resonance imaging of the sacroiliac joint and lumbar spine in very early inflammatory back pain. Relationship between symptoms, HLA-B27 and disease extent and persistence. Ann Rheum Dis 2009;68:1721-7.

21 Oostveen J, Prevo R, den Boer J, et al. Early detection of sacroiliitis on magnetic resonance imaging and subsequent development of sacroiliitis on plain radiography. A prospective, longitudinal study. J Rheumatol 1999;26: 1953-8.

22 Weber U, Lambert RG, Pedersen SJ, et al. Assessment of structural lesions in sacroiliac joints enhances diagnostic utility of magnetic resonance imaging in early spondylarthritis. Arthritis Care Res (Hoboken) 2010;62:1763-71.

23 Weber $U$, Lambert RG, Østergaard $M$, et al. The diagnostic utility of magnetic resonance imaging in spondylarthritis: an international multicenter evaluation of one hundred eighty-seven subjects. Arthritis Rheum 2010;62:3048-58.

24 Weber U, Pedersen SJ, Zubler V, et al. What constitutes the characteristic fat lesion on MRI of the sacroiliac joints in early spondyloarthritis? Arthritis Rheum 2012;64 (Suppl 10):1024.

25 Weber U, Zubler V, Pedersen SJ, et al. Development and validation of a magnetic resonance imaging reference criterion for defining a positive sacroiliac joint magnetic resonance imaging finding in spondyloarthritis. Arthritis Care Res Hoboken 2013;65:977-85.

26 Wick MC, Weiss RJ, Jaschke W, et al. Erosions are the most relevant magnetic resonance imaging features in quantification of sacroiliac joints in ankylosing spondylitis. J Rheumatol 2010;37:622-7.

27 Heuft-Dorenbosch L, Landewé R, Weijers R, et al. Combining information obtained from magnetic resonance imaging and conventional radiographs to detect sacroiliitis in patients with recent onset inflammatory back pain. Ann Rheum Dis 2006;65:804-8.

28 Bennett AN, Rehman A, Hensor EM, et al. Evaluation of the diagnostic utility of spinal magnetic resonance imaging in axial spondylarthritis. Arthritis Rheum 2009;60:1331-41

29 Bennett AN, Rehman A, Hensor EM, et al. The fatty Romanus lesion: a non-inflammatory spinal MRI lesion specific for axial spondyloarthropathy. Ann Rheum Dis 2010;69:891-4.

30 Weber U, Hodler J, Kubik RA, et al. Sensitivity and specificity of spinal inflammatory lesions assessed by whole-body magnetic resonance imaging in patients with ankylosing spondylitis or recent-onset inflammatory back pain. Arthritis Rheum 2009;61:900-8.

31 Kim NR, Choi JY, Hong SH, et al. "MR corner sign": value for predicting presence of ankylosing spondylitis. AJR Am J Roentgenol 2008;191:124-8.

32 Weber U, Zubler V, Zhao Z, et al. Does spinal MRI add incremental diagnostic value to MRI of the sacroiliac joints alone in patients with non-radiographic axial spondyloarthritis? Ann Rheum Dis 2015;74:985-92.

33 Inanc N, Atagündüz $P$, Sen $F$, et al. The investigation of sacroiliitis with different imaging techniques in spondyloarthropathies. Rheumatol Int 2005;25:591-4.

34 Chase WF, Houk RW, Winn RE, et al. The clinical usefulness of radionuclide scintigraphy in suspected sacro-iliitis: a prospective study. Br J Rheumatol 1983;22:67-72.

35 Song $\mathrm{IH}$, Brandt $\mathrm{H}$, Rudwaleit $\mathrm{M}$, et al. Limited diagnostic value of unilateral sacroiliitis in scintigraphy in assessing axial spondyloarthritis. J Rheumatol 2010;37:1200-2.

36 Klauser A, Halpern EJ, Frauscher F, et al. Inflammatory low back pain: high negative predictive value of contrast-enhanced color Doppler ultrasound in the detection of inflamed sacroiliac joints. Arthritis Rheum 2005;53:440-4.

37 Klauser AS, De Zordo T, Bellmann-Weiler R, et al. Feasibility of second-generation ultrasound contrast media in the detection of active sacroiliitis. Arthritis Rheum 2009;61:909-16.

38 Mohammadi A, Ghasemi-rad M, Aghdashi M, et al. Evaluation of disease activity in ankylosing spondylitis; diagnostic value of color Doppler ultrasonography. Skeletal Radiol 2013;42:219-24.

39 Aydin SZ, Ash ZR, Tinazzi l, et al. The link between enthesitis and arthritis in psoriatic arthritis: a switch to a vascular phenotype at insertions may play a role in arthritis development. Ann Rheum Dis 2013;72:992-5.

40 D'Agostino MA, Said-Nahal R, Hacquard-Bouder C, et al. Assessment of peripheral enthesitis in the spondylarthropathies by ultrasonography combined with power Doppler: a cross-sectional study. Arthritis Rheum 2003;48:523-33.
41 D'Agostino MA, Aegerter P, Bechara K, et al. How to diagnose spondyloarthritis early? Accuracy of peripheral enthesitis detection by power Doppler ultrasonography. Ann Rheum Dis 2011;70:1433-40.

42 de Miguel E, Cobo T, Muñoz-Fernández $\mathrm{S}$, et al. Validity of enthesis ultrasound assessment in spondyloarthropathy. Ann Rheum Dis 2009;68:169-74.

43 de Miguel E, Muñoz-Fernández S, Castillo C, et al. Diagnostic accuracy of enthesis ultrasound in the diagnosis of early spondyloarthritis. Ann Rheum Dis 2011;70:434-9.

44 Feydy A, Lavie-Brion MC, Gossec L, et al. Comparative study of MRI and power Doppler ultrasonography of the heel in patients with spondyloarthritis with and without heel pain and in controls. Ann Rheum Dis 2012;71:498-503.

45 Ibrahim G, Groves C, Chandramohan M, et al. Clinical and ultrasound examination of the leeds enthesitis index in psoriatic arthritis and rheumatoid arthritis. ISRN Rheumatol 2011;2011:731917

46 Marchesoni A, De Lucia O, Rotunno L, et al. Entheseal power Doppler ultrasonography: a comparison of psoriatic arthritis and fibromyalgia. J Rheumatol 2012;89:29-31.

47 Farouk HM, Mostafa AA, Youssef SS, et al. Value of entheseal ultrasonography and serum cartilage oligomeric matrix protein in the preclinical diagnosis of psoriatic arthritis. Clin Med Insights Arthritis Musculoskelet Disord 2010;3:7-14

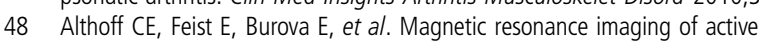
sacroiliitis: do we really need gadolinium? Eur J Radiol 2009;71:232-6.

49 Baraliakos $X$, Hermann KG, Landewé $R$, et al. Assessment of acute spinal inflammation in patients with ankylosing spondylitis by magnetic resonance imaging: a comparison between contrast enhanced $\mathrm{T} 1$ and short tau inversion recovery (STIR) sequences. Ann Rheum Dis 2005;64:1141-4.

50 Baraliakos X, Davis J, Tsuji W, et al. Magnetic resonance imaging examinations of the spine in patients with ankylosing spondylitis before and after therapy with the tumor necrosis factor alpha receptor fusion protein etanercept. Arthritis Rheum 2005;52:1216-23.

51 Blachier M, Coutanceau B, Dougados M, et al. Does the site of magnetic resonance imaging abnormalities match the site of recent-onset inflammatory back pain? The DESIR cohort. Ann Rheum Dis 2013;72:979-85.

52 Bonel HM, Boller C, Saar B, et al. Short-term changes in magnetic resonance imaging and disease activity in response to infliximab. Ann Rheum Dis 2010;69:120-5.

53 Braun J, Baraliakos X, Golder W, et al. Magnetic resonance imaging examinations of the spine in patients with ankylosing spondylitis, before and after successful therapy with infliximab: evaluation of a new scoring system. Arthritis Rheum 2003;48:1126-36.

54 Braun J, Baraliakos X, Hermann KG, et al. Golimumab reduces spinal inflammation in ankylosing spondylitis: MRI results of the randomised, placebo- controlled GO-RAISE study. Ann Rheum Dis 2012;71:878-84.

55 Goh L, Suresh P, Gafoor A, et al. Disease activity in longstanding ankylosing spondylitis: a correlation of clinical and magnetic resonance imaging findings. Clin Rheumatol 2008;27:449-55.

56 de Hooge M, van den Berg R, Navarro-Compán V, et al. Magnetic resonance imaging of the sacroiliac joints in the early detection of spondyloarthritis: no added value of gadolinium compared with short tau inversion recovery sequence. Rheumatology (Oxford) 2013;52:1220-4.

57 Hermann KG, Landewé RB, Braun J, et al. Magnetic resonance imaging of inflammatory lesions in the spine in ankylosing spondylitis clinical trials: is paramagnetic contrast medium necessary? J Rheumatol 2005;32:2056-60.

$58 \mathrm{Hu}$ Z, Xu M, Li Q, et al. Adalimumab significantly reduces inflammation and serum DKK-1 level but increases fatty deposition in lumbar spine in active ankylosing spondylitis. Int J Rheum Dis 2012;15:358-65.

59 Kiltz U, Baraliakos X, Karakostas $P$, et al. The degree of spinal inflammation is similar in patients with axial spondyloarthritis who report high or low levels of disease activity: a cohort study. Ann Rheum Dis 2012;71:1207-11.

60 Konca S, Keskin D, Ciliz D, et al. Spinal inflammation by magnetic resonance imaging in patients with ankylosing spondylitis: association with disease activity and outcome parameters. Rheumatol Int 2012;32:3765-70.

61 Lambert RG, Salonen D, Rahman P, et al. Adalimumab significantly reduces both spinal and sacroiliac joint inflammation in patients with ankylosing spondylitis: a multicenter, randomized, double-blind, placebo-controlled study. Arthritis Rheum 2007;56:4005-14

62 Lukas C, Braun J, van der Heijde D, et al. Scoring inflammatory activity of the spine by magnetic resonance imaging in ankylosing spondylitis: a multireader experiment. J Rheumatol 2007;34:862-70.

63 Machado P, Landewé R, Braun J, et al. A stratified model for health outcomes in ankylosing spondylitis. Ann Rheum Dis 2011;70:1758-64.

64 Machado P, Landewé RB, Braun J, et al. MRI inflammation and its relation with measures of clinical disease activity and different treatment responses in patients with ankylosing spondylitis treated with a tumour necrosis factor inhibitor. Ann Rheum Dis 2012;71:2002-5.

65 Madsen KB, Egund N, Jurik AG. Grading of inflammatory disease activity in the sacroiliac joints with magnetic resonance imaging: comparison between short-tau 
inversion recovery and gadolinium contrast-enhanced sequences. I Rheumatol 2010;37:393-400.

66 Maksymowych WP, Dhillon SS, Park R, et al. Validation of the spondyloarthritis research consortium of Canada magnetic resonance imaging spinal inflammation index: is it necessary to score the entire spine? Arthritis Rheum 2007;57:501-7.

67 Maksymowych WP, Salonen D, Inman RD, et al. Low-dose infliximab (3 mg/kg) significantly reduces spinal inflammation on magnetic resonance imaging in patients with ankylosing spondylitis: a randomized placebo-controlled study. J Rheumatol 2010;37:1728-34.

68 Marzo-Ortega H, McGonagle D, Jarrett S, et al. Infliximab in combination with methotrexate in active ankylosing spondylitis: a clinical and imaging study. Ann Rheum Dis 2005;64:1568-75.

69 Pedersen SJ, Sørensen IJ, Hermann KG, et al. Responsiveness of the Ankylosing Spondylitis Disease Activity Score (ASDAS) and clinical and MRI measures of disease activity in a 1-year follow-up study of patients with axial spondyloarthritis treated with tumour necrosis factor alpha inhibitors. Ann Rheum Dis 2010;69:1065-71.

70 Puhakka KB, Jurik AG, Schiottz-Christensen B, et al. Magnetic resonance imaging of sacroiliitis in early seronegative spondylarthropathy. Abnormalities correlated to clinical and laboratory findings. Rheumatology (Oxford) 2004;43:234-7.

71 Puhakka KB, Jurik AG, Schiøttz-Christensen B, et al. MRI abnormalities of sacroiliac joints in early spondylarthropathy: a 1-year follow-up study. Scand J Rheumatol 2004;33:332-8.

72 Rudwaleit M, Baraliakos $X$, Listing J, et al. Magnetic resonance imaging of the spine and the sacroiliac joints in ankylosing spondylitis and undifferentiated spondyloarthritis during treatment with etanercept. Ann Rheum Dis 2005:64:1305-10.

73 Rudwaleit M, Schwarzlose S, Hilgert ES, et al. MRI in predicting a major clinical response to anti-tumour necrosis factor treatment in ankylosing spondylitis. Ann Rheum Dis 2008:67:1276-81.

74 Sieper J, Baraliakos $X$, Listing J, et al. Persistent reduction of spinal inflammation as assessed by magnetic resonance imaging in patients with ankylosing spondylitis after 2 yrs of treatment with the anti-tumour necrosis factor agent infliximab. Rheumatology (Oxford) 2005;44:1525-30.

75 Sieper J, van der Heijde D, Dougados M, et al. Efficacy and safety of adalimumab in patients with non-radiographic axial spondyloarthritis: results of a randomised placebo-controlled trial (ABILITY-1). Ann Rheum Dis 2013;72:815-22.

76 Song $\mathrm{IH}$, Hermann $\mathrm{K}$, Haibel $\mathrm{H}$, et al. Effects of etanercept versus sulfasalazine in early axial spondyloarthritis on active inflammatory lesions as detected by whole-body MRI (ESTHER): a 48-week randomised controlled trial. Ann Rheum Dis 2011:70:590-6.

77 Visvanathan S, Wagner C, Marini JC, et al. Inflammatory biomarkers, disease activity and spinal disease measures in patients with ankylosing spondylitis after treatment with infliximab. Ann Rheum Dis 2008;67:511-17.

78 Weber U, Maksymowych WP, Jurik AG. Validation of whole-body against conventional magnetic resonance imaging for scoring acute inflammatory lesions in the sacroiliac joints of patients with spondylarthritis. Arthritis Rheum 2009;61:893-9

79 Weber U, Lambert RG, Rufibach K, et al. Anterior chest wall inflammation by whole-body magnetic resonance imaging in patients with spondyloarthritis: lack of association between clinical and imaging findings in a cross-sectional study. Arthritis Res Ther 2012:14:R3.

80 Akgul O, Gulkesen A, Akgol G, et al. MR-defined fat infiltration of the lumbar paravertebral muscles differs between non-radiographic axial spondyloarthritis and established ankylosing spondylitis. Mod Rheumatol 2013;23:811-16.

81 Averns HL, Oxtoby J, Taylor HG, et al. Radiological outcome in ankylosing spondylitis: use of the Stoke Ankylosing Spondylitis Spine Score (SASSS). Br J Rheumatol 1996:35:373-6.

82 Baraliakos X, Listing J, Rudwaleit M, et al. Radiographic progression in patients with ankylosing spondylitis after 2 years of treatment with the tumour necrosis factor alpha antibody infliximab. Ann Rheum Dis 2005;64:1462-6.

83 Baraliakos $\mathrm{X}$, Listing J, Rudwaleit $\mathrm{M}$, et al. Development of a radiographic scoring tool for ankylosing spondylitis only based on bone formation: addition of the thoracic spine improves sensitivity to change. Arthritis Rheum 2009;61:764-71.

84 Braun J, Baraliakos X, Golder W, et al. Analysing chronic spinal changes in ankylosing spondylitis: a systematic comparison of conventional $X$ rays with magnetic resonance imaging using established and new scoring systems. Ann Rheum Dis 2004;63:1046-55.

85 Creemers MC, Franssen MJ, van't Hof MA, et al. Assessment of outcome in ankylosing spondylitis: an extended radiographic scoring system. Ann Rheum Dis 2005:64:127-9.

86 Lee JY, Kim JI, Park JY, et al. Cervical spine involvement in longstanding ankylosing spondylitis. Clin Exp Rheumatol 2005;23:331-8.

87 Lubrano E, Marchesoni A, Olivieri I, et al. The radiological assessment of axial involvement in psoriatic arthritis: a validation study of the BASRI total and the modified SASSS scoring methods. Clin Exp Rheumatol 2009;27:977-80.
88 Machado P, Landewe R, Braun J, et al. In ankylosing spondylitis, a decrease in MRI spinal inflammation predicts improvement in spinal mobility independently of patient reported symptomatic improvement. Arthritis Rheum 2012;64(Suppl 10):563.

89 Madsen KB, Jurik AG. Magnetic resonance imaging grading system for active and chronic spondylarthritis changes in the sacroiliac joint. Arthritis Care Res (Hoboken) 2010;62:11-18

90 Madsen KB, Jurik AG. MRI grading method for active and chronic spinal changes in spondyloarthritis. Clin Radiol 2010;65:6-14.

91 Puhakka KB, Jurik AG, Egund N, et al. Imaging of sacroilitis in early seronegative spondylarthropathy. Assessment of abnormalities by MR in comparison with radiography and CT. Acta Radiol 2003;44:218-29.

92 Ramiro S, van Tubergen A, Stolwijk C, et al. Scoring radiographic progression in ankylosing spondylitis: should we use the modified Stoke Ankylosing Spondylitis Spine Score (mSASSS) or the Radiographic Ankylosing Spondylitis Spinal Score (RASSS)? Arthritis Res Ther 2013;15:R14.

93 Salaffi F, Carotti M, Garofalo G, et al. Radiological scoring methods for ankylosing spondylitis: a comparison between the Bath Ankylosing Spondylitis Radiology Index and the modified Stoke Ankylosing Spondylitis Spine Score. Clin Exp Rheumatol 2007;25:67-74.

94 Taylor HG, Wardle T, Beswick EJ, et al. The relationship of clinical and laboratory measurements to radiological change in ankylosing spondylitis. $\mathrm{Br} J$ Rheumatol 1991;30:330-5.

95 Taylor HG, Gadd R, Beswick EJ, et al. Quantitative radio-isotope scanning in ankylosing spondylitis: a clinical, laboratory and computerised tomographic study. Scand I Rheumatol 1991;20:274-9.

96 Wanders AJ, Landewé RB, Spoorenberg A, et al. What is the most appropriate radiologic scoring method for ankylosing spondylitis? A comparison of the available methods based on the Outcome Measures in Rheumatology Clinical Trials filter. Arthritis Rheum 2004;50:2622-32.

97 Williamson L, Dockerty JL, Dalbeth N, et al. Clinical assessment of sacroiliitis and HLA-B27 are poor predictors of sacroilititis diagnosed by magnetic resonance imaging in psoriatic arthritis. Rheumatology (Oxford) 2004;43:85-8.

98 Naredo E, Batlle-Gualda E, García-Vivar ML, et al. Power Doppler ultrasonography assessment of entheses in spondyloarthropathies: response to therapy of entheseal abnormalities. J Rheumatol 2010;37:2110-17.

99 Hamdi W, Chelli-Bouaziz M, Ahmed MS, et al. Correlations among clinical, radiographic, and sonographic scores for enthesitis in ankylosing spondylitis. Joint Bone Spine 2011;78:270-4.

100 Aydin SZ, Karadag O, Filippucci E, et al. Monitoring Achilles enthesitis in ankylosing spondylitis during TNF-alpha antagonist therapy: an ultrasound study. Rheumatology (Oxford) 2010;49:578-82.

101 Borman P, Koparal S, Babaoğlu S, et al. Ultrasound detection of entheseal insertions in the foot of patients with spondyloarthropathy. Clin Rheumatol 2006:25:373-7.

102 Kiris A, Kaya A, Ozgocmen $S$, et al. Assessment of enthesitis in ankylosing spondylitis by power Doppler ultrasonography. Skeletal Radiol 2006;35:522-8.

103 Balint PV, Kane D, Wilson $\mathrm{H}$, et al. Ultrasonography of entheseal insertions in the lower limb in spondyloarthropathy. Ann Rheum Dis 2002;61:905-10.

104 Milosavljevic J, Lindqvist U, Elvin A. Ultrasound and power Doppler evaluation of the hand and wrist in patients with psoriatic arthritis. Acta Radiol 2005;46:374-85.

105 Spadaro A, lagnocco A, Perrotta FM, et al. Clinical and ultrasonography assessment of peripheral enthesitis in ankylosing spondylitis. Rheumatology (Oxford) 2011;50:2080-6.

106 McQueen F, Lassere M, Duer-Jensen A, et al. Testing an OMERACT MRI scoring system for peripheral psoriatic arthritis in cross-sectional and longitudinal settings. J Rheumatol 2009;36:1811-15.

107 Mease P, Genovese MC, Gladstein G, et al. Abatacept in the treatment of patients with psoriatic arthritis: results of a six-month, multicenter, randomized, double-blind, placebo-controlled, phase II trial. Arthritis Rheum 2011;63:939-48.

108 Poggenborg RP, Boyesen P, Wiell C, et al. Reduction in MRI inflammation during adalimumab therapy in patients with psoriatic arthritis implementation of the OMERACT PsAMRIS scoring method in a follow-up study. Arthritis Rheum 2011;63(Suppl 10):953.

109 Bennett AN, Marzo-Ortega H, Tan AL, et al. Ten-year follow-up of SpA-related oligoarthritis involving the knee: the presence of psoriasis but not HLA-B27 or baseline MRI bone oedema predicts outcome. Rheumatology (Oxford) 2012;51:1099-106.

110 Tan YM, Østergaard M, Doyle A, et al. MRI bone oedema scores are higher in the arthritis mutilans form of psoriatic arthritis and correlate with high radiographic scores for joint damage. Arthritis Res Ther 2009;11:R2.

111 Blackmore MG, Gladman DD, Husted J, et al. Measuring health status in psoriatic arthritis: the Health Assessment Questionnaire and its modification. I Rheumatol 1995;22:886-93.

112 Könönen $\mathrm{M}$, Kovero $\mathrm{O}$, Wenneberg $\mathrm{B}$, et al. Radiographic signs in the temporomandibular joint in Reiter's disease. J Orofac Pain 2002;16:143-7.

113 Rahman P, Gladman DD, Cook RJ, et al. Radiological assessment in psoriatic arthritis. Br J Rheumatol 1998;37:760-5. 
114 Ravindran J, Cavill C, Balakrishnan C, et al. A modified Sharp score demonstrates disease progression in established psoriatic arthritis. Arthritis Care Res (Hoboken) 2010;62:86-91.

115 Taccari E, Spadaro A, Rinaldi T, et al. Comparison of the Health Assessment Questionnaire and Arthritis Impact Measurement Scale in patients with psoriatic arthritis. Rev Rhum Engl Ed 1998;65:751-8.

116 Baraliakos X, Listing J, Rudwaleit M, et al. Progression of radiographic damage in patients with ankylosing spondylitis: defining the central role of syndesmophytes. Ann Rheum Dis 2007;66:910-15.

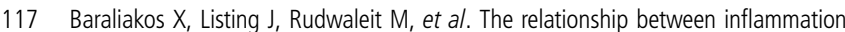
and new bone formation in patients with ankylosing spondylitis. Arthritis Res Ther 2008:10:R104.

118 Baraliakos X, Listing J, von der Recke A, et al. The natural course of radiographic progression in ankylosing spondylitis-evidence for major individual variations in a large proportion of patients. J Rheumatol 2009;36:997-1002.

119 Baraliakos X, Heldmann F, Listing J, et al. The relationship of inflammation, fatty degeneration and the effect of long-term TNF-blocker treatment on the development of new bone formation in patients with ankylosing spondylitis. Arthritis Rheum 2012;64(Suppl 10):780.

120 Chiowchanwisawakit P, Lambert RG, Conner-Spady B, et al. Focal fat lesions at vertebral corners on magnetic resonance imaging predict the development of new syndesmophytes in ankylosing spondylitis. Arthritis Rheum 2011;63:2215-25

121 Madsen KB, Schiøttz-Christensen B, Jurik AG. Prognostic significance of magnetic resonance imaging changes of the sacroiliac joints in spondyloarthritis-a followup study. J Rheumatol 2010;37:1718-27.

122 Maksymowych WP, Landewé R, Conner-Spady B, et al. Serum matrix metalloproteinase 3 is an independent predictor of structural damage progression in patients with ankylosing spondylitis. Arthritis Rheum 2007:56:1846-53

123 Maksymowych WP, Chiowchanwisawakit P, Clare T, et al. Inflammatory lesions of the spine on magnetic resonance imaging predict the development of new syndesmophytes in ankylosing spondylitis: evidence of a relationship between inflammation and new bone formation. Arthritis Rheum 2009;60:93-102.

124 Pedersen SJ, Chiowchanwisawakit P, Lambert RG, et al. Resolution of inflammation following treatment of ankylosing spondylitis is associated with new bone formation. J Rheumatol 2011;38:1349-54.

125 Pedersen SJ, Sørensen IJ, Lambert RG, et al. Radiographic progression is associated with resolution of systemic inflammation in patients with axial spondylarthritis treated with tumor necrosis factor $\alpha$ inhibitors: a study of radiographic progression, inflammation on magnetic resonance imaging, and circulating biomarkers of inflammation, angiogenesis, and cartilage and bone turnover. Arthritis Rheum 2011:63:3789-800.

126 Poddubnyy D, Haibel H, Listing J, et al. Baseline radiographic damage, elevated acute-phase reactant levels, and cigarette smoking status predict spinal radiographic progression in early axial spondylarthritis. Arthritis Rheum 2012;64:1388-98

127 Song $\mathrm{IH}$, Hermann $\mathrm{KG}$, Haibel $\mathrm{H}$, et al. Relationship between active inflammatory lesions in the spine and sacroiliac joints and new development of chronic lesions on whole-body MRI in early axial spondyloarthritis: results of the ESTHER trial at week 48. Ann Rheum Dis 2011;70:1257-63.

128 van der Heijde D, Machado P, Braun J, et al. MRI inflammation at the vertebral unit only marginally predicts new syndesmophyte formation: a multilevel analysis in patients with ankylosing spondylitis. Ann Rheum Dis 2012;71:369-73.

129 van Tubergen A, Ramiro S, van der Heijde D, et al. Development of new syndesmophytes and bridges in ankylosing spondylitis and their predictors: a longitudinal study. Ann Rheum Dis 2012;71:518-23.

130 Barkham N, Keen HI, Coates LC, et al. Clinical and imaging efficacy of infliximab in HLA-B27-Positive patients with magnetic resonance imaging-determined early sacroiliitis. Arthritis Rheum 2009;60:946-54.

131 Nakstad PH, Server A, Josefsen R. Traumatic cervical injuries in ankylosing spondylitis. Acta Radiol 2004;45:222-6.

132 Katzberg RW, Benedetti PF, Drake CM, et al. Acute cervical spine injuries: prospective MR imaging assessment at a level 1 trauma center. Radiology 1999:213:203-12

133 Jansen TL, Aarts MH, Zanen S, et al. Risk assessment for osteoporosis by quantitative ultrasound of the heel in ankylosing spondylitis. Clin Exp Rheumatol 2003;21:599-604

134 Frediani B, Allegri A, Falsetti $\mathrm{P}$, et al. Bone mineral density in patients with psoriatic arthritis. J Rheumatol 2001;28:138-43.

135 Speden DJ, Calin Al, Ring FJ, et al. Bone mineral density, calcaneal ultrasound, and bone turnover markers in women with ankylosing spondylitis. J Rheumatol 2002;29:516-21.

136 Toussirot E, Michel F, Wendling D. Bone density, ultrasound measurements and body composition in early ankylosing spondylitis. Rheumatology (Oxford) $2001 ; 40: 882-8$
137 Devogelaer JP, Maldague B, Malghem J, et al. Appendicular and vertebral bone mass in ankylosing spondylitis. A comparison of plain radiographs with single- and dual-photon absorptiometry and with quantitative computed tomography. Arthritis Rheum 2002;35:1062-7.

138 Karberg K, Zochling J, Sieper J, et al. Bone loss is detected more frequently in patients with ankylosing spondylitis with syndesmophytes. J Rheumatol 2005;32:1290-8.

139 Altindag 0 , Karakoc M, Soran N, et al. Bone mineral density in patients with ankylosing spondylitis. Romatizma 2008;23:42-5.

140 Jun JB, Joo KB, Her MY, et al. Femoral bone mineral density is associated with vertebral fractures in patients with ankylosing spondylitis: a cross-sectional study. J Rheumatol 2006;33:1637-41.

141 Meirelles ES, Borelli A, Camargo OP. Influence of disease activity and chronicity on ankylosing spondylitis bone mass loss. Clin Rheumatol 1999;18:364-8.

142 Mullaji AB, Upadhyay SS, Ho EK. Bone mineral density in ankylosing spondylitis. DEXA comparison of control subjects with mild and advanced cases. J Bone Joint Surg $\mathrm{Br} 1994 ; 76: 660-5$.

143 Will R, Palmer R, Bhalla AK, et al. Osteoporosis in early ankylosing spondylitis: a primary pathological event? Lancet 1989;2:1483-5.

144 Franck H, Meurer T, Hofbauer LC. Evaluation of bone mineral density, hormones, biochemical markers of bone metabolism, and osteoprotegerin serum levels in patients with ankylosing spondylitis. J Rheumatol 2004;31:2236-41.

145 Gilgil E, Kaçar C, Tuncer T, et al. The association of syndesmophytes with vertebra bone mineral density in patients with ankylosing spondylitis. J Rheumatol 2005;32:292-4.

146 Mermerci Başkan B, Pekin Doğan Y, Sivas F, et al. The relation between osteoporosis and vitamin D levels and disease activity in ankylosing spondylitis. Rheumatol Int 2010;30:375-81.

147 Muntean L, Rojas-Vargas M, Font $\mathrm{P}$, et al. Relative value of the lumbar spine and hip bone mineral density and bone turnover markers in men with ankylosing spondylitis. Clin Rheumatol 2011;30:691-5.

148 Taylan A, Sari I, Akinci B, et al. Biomarkers and cytokines of bone turnover: extensive evaluation in a cohort of patients with ankylosing spondylitis. $B M C$ Musculoskelet Disord 2012;13:191.

149 Ulu MA, Çevik R, Dilek B. Comparison of PA spine, lateral spine, and femoral BMD measurements to determine bone loss in ankylosing spondylitis. Rheumatol Int 2012;29:29.

150 Will R, Palmer R, Bhalla AK, et al. Bone loss as well as bone formation is a feature of progressive ankylosing spondylitis. $\mathrm{Br} J$ Rheumatol 1990;29:498-9

151 Vasdev V, Bhakuni D, Garg MK, et al. Bone mineral density in young males with ankylosing spondylitis. Int J Rheum Dis 2011;14:68-73.

152 Korczowska I, Przepiera-Bedzak H, Brzosko M, et al. Bone tissue metabolism in men with ankylosing spondylitis. Adv Med Sci 2011;56:264-9.

153 Sarikaya S, Basaran A, Tekin Y, et al. Is osteoporosis generalized or localized to central skeleton in ankylosing spondylitis? J Clin Rheumatol 2007;13:20-4

154 Baek HJ, Kang SW, Lee YJ, et al. Osteopenia in men with mild and severe ankylosing spondylitis. Rheumatol Int 2005;26:30-4.

155 Capaci $K$, Hepguler S, Argin M, et al. Bone mineral density in mild and advanced ankylosing spondylitis. Yonsei Med J 2003;44:379-84.

156 Donnelly S, Doyle DV, Denton A, et al. Bone mineral density and vertebral compression fracture rates in ankylosing spondylitis. Ann Rheum Dis 1994;53:117-21.

157 Klingberg E, Lorentzon M, Mellström D, et al. Osteoporosis in ankylosing spondylitis-prevalence, risk factors and methods of assessment. Arthritis Res The 2012:14:R108

158 Grazio S, Kusić Z, Cvijetić S, et al. Relationship of bone mineral density with disease activity and functional ability in patients with ankylosing spondylitis: a cross-sectional study. Rheumatol Int 2012;32:2801-8.

159 Park MC, Chung SJ, Park YB, et al. Bone and cartilage turnover markers, bone mineral density, and radiographic damage in men with ankylosing spondylitis. Yonsei Med J 2008;49:288-94.

160 van der Weijden MA, van Denderen JC, Lems WF, et al. Low bone mineral density is related to male gender and decreased functional capacity in early spondylarthropathies. Clin Rheumatol 2011;30:497-503.

161 Grisar J, Bernecker PM, Aringer M, et al. Ankylosing spondylitis, psoriatic arthritis, and reactive arthritis show increased bone resorption, but differ with regard to bone formation. J Rheumatol 2002;29:1430-6.

162 Pedreira PG, Pinheiro MM, Szejnfeld VL. Bone mineral density and body composition in postmenopausal women with psoriasis and psoriatic arthritis. Arthritis Res Ther 2011;13:R16.

163 Dheda K, Cassim B, Patel N, et al. A comparison of bone mineral density in Indians with psoriatic polyarthritis and healthy Indian volunteers. Clin Rheumatol 2004;23:89

164 Grazio S, Cvijetić S, Vlak T, et al. Osteoporosis in psoriatic arthritis: is there any? Wien Klin Wochenschr 2011;123:743-50. 
165 Gratacós J, Collado A, Pons F, et al. Significant loss of bone mass in patients with early, active ankylosing spondylitis: a followup study. Arthritis Rheum 1999;42:2319-24.

166 Haugeberg G, Bennett AN, McGonagle D, et al. Bone loss in very early inflammatory back pain in undifferentiated spondyloarthropathy: a 1-year observational study. Ann Rheum Dis 2010;69:1364-6.

167 Kaya A, Ozgocmen S, Kamanli A, et al. Bone loss in ankylosing spondylitis: does syndesmophyte formation have an influence on bone density changes? Med Princ Pract 2009; 18:470-6.

168 Maillefert JF, Aho LS, El Maghraoui A, et al. Changes in bone density in patients with ankylosing spondylitis: a two-year follow-up study. Osteoporos Int 2001;12:605-9.

169 Anandarajah AP, El-Taha M, Peng C, et al. Association between focal erosions and generalised bone loss in psoriatic arthritis. Ann Rheum Dis 2011;70:1345-7.

170 Arends S, Spoorenberg A, Bruyn GA, et al. The relation between bone mineral density, bone turnover markers, and vitamin D status in ankylosing spondylitis patients with active disease: a cross-sectional analysis. Osteoporos Int 2011;22:1431-9.
171 Briot K, Durnez A, Paternotte $\mathrm{S}$, et al. Bone oedema on MRI is highly associated with low bone mineral density in patients with early inflammatory back pain: results from the DESIR cohort. Ann Rheum Dis 2013;72:1914-19.

172 Dos Santos FP, Constantin A, Laroche M, et al. Whole body and regional bone mineral density in ankylosing spondylitis. J Rheumatol 2001;28:547-9.

173 El Maghraoui A, Borderie D, Cherruau B, et al. Osteoporosis, body composition, and bone turnover in ankylosing spondylitis. J Rheumatol 1999;26:2205-9.

174 Mitra D, Elvins DM, Collins AJ. Biochemical markers of bone metabolism in mild ankylosing spondylitis and their relationship with bone mineral density and vertebral fractures. J Rheumatol 1999;26:2201-4.

175 Lange U, Kluge A, Strunk J, et al. Ankylosing spondylitis and bone mineral density - what is the ideal tool for measurement? Rheumatol Int 2005;26:115-20.

176 Schueller-Weidekamm C, Mascarenhas VV, Sudol-Szopinska I, et al. Imaging and interpretation of axial spondylarthritis: the radiologist's perspectiveconsensus of the Arthritis Subcommittee of the ESSR. Semin Musculoskelet Radiol 2014; 18:265-79. 